Article

\title{
Poor Air Quality in Urban Settings: A Comparison of Perceptual Indicators, Causes and Management in Two Cities
}

\author{
Timothy M. Chukwu *(i), Stephen Morse (i) and Richard Murphy (i)
}

check for updates

Citation: Chukwu, T.M.; Morse, S.; Murphy, R. Poor Air Quality in Urban Settings: A Comparison of Perceptual Indicators, Causes and Management in Two Cities. Sustainability 2022, 14, 1438. https:// doi.org/10.3390/su14031438

Academic Editor: Roope Husgafvel

Received: 15 December 2021

Accepted: 19 January 2022

Published: 27 January 2022

Publisher's Note: MDPI stays neutral with regard to jurisdictional claims in published maps and institutional affiliations.

Copyright: (C) 2022 by the authors. Licensee MDPI, Basel, Switzerland. This article is an open access article distributed under the terms and conditions of the Creative Commons Attribution (CC BY) license (https:// creativecommons.org/licenses/by/ $4.0 /)$.
Centre for Environment and Sustainability, Faculty of Physical Sciences and Engineering, University of Surrey, Guildford GU2 7XH, UK; s.morse@surrey.ac.uk (S.M.); rj.murphy@surrey.ac.uk (R.M.)

* Correspondence: t.chukwu@surrey.ac.uk

\begin{abstract}
Poor air quality (PAQ) is a global concern, especially in urban areas, and is often seen as an important element of social sustainability given its negative impact on health and quality of life. However, little research has been undertaken in cities of the developing world to explore how residents perceive poor air quality, its main causes, what control measures should be used to address PAQ and where the main responsibility rests for implementing control measures. The research described in this paper sought to address these points, using a questionnaire-based survey $(n=262)$ in Nigeria's federal capital city of Abuja $(n=137)$ and the state-capital city of Enugu $(n=125)$. The survey took place during the COVID-19 pandemic (October 2020 to March 2021), and was stratified to ensure representation across a number of demographic groups such as gender, age, education and income. The results were analysed using the Kruskal-Wallis non-parametric test and Hochberg's post hoc test available in SPSS version 28. The study found that the ranking of perceptual indicators and the main causes of PAQ had much agreement between respondents from both cities and between demographic groups. Smoke, odour and dust particles were perceived to be the most important indicators of PAQ, while the main sources of PAQ were waste and bush burning, vehicle use and power generators. The two most preferred control measures were proper waste management and the avoidance of bush burning. However, there was a significant difference between the two cities in terms of the main organisations responsible for addressing PAQ, with respondents from Abuja citing the federal government, while those from Enugu cited the state government. Interestingly, younger people in Enugu noted that the government should take more responsibility in controlling PAQ than did the older demographic in that city, but this difference was not seen in Abuja. Overall, this study reveals that residents in these two Nigerian cities clearly recognise their exposure to PAQ and it suggests that these perceptual indicators, and views on sources and interventions should be central to designing policies to control this important issue.
\end{abstract}

Keywords: air quality; cities; perceptual indicators; causes; control measures; responsibility; ethnicity; youth; Nigeria

\section{Introduction}

The steady upsurge in urban populations, particularly in developing nations, has led to increases in poor air quality (PAQ) [1-5]. Air pollutants such as oxides of nitrogen $\left(\mathrm{NO}_{\mathrm{x}}\right)$, sulphur dioxide $\left(\mathrm{SO}_{2}\right)$, carbon monoxide $(\mathrm{CO})$, ozone $\left(\mathrm{O}_{3}\right)$, ammonia $\left(\mathrm{NH}_{3}\right)$, volatile organic compounds (VOCs), particulate matter ( $\mathrm{PM})$, lead $(\mathrm{Pb})$ and so on contribute to adverse effects on human and ecosystem health, and this can in turn impact negatively on social sustainability [5]. The World Health Organization (WHO) reported that approximately 7 million premature deaths recorded globally each year can be attributed to PAQ [6], and the majority of the deaths occur in areas that have worse air quality than the WHO's guideline limits on pollutants such as $\mathrm{SO}_{2}, \mathrm{O}_{3}, \mathrm{CO}, \mathrm{NO}_{2}, \mathrm{PM}$ [7]. In addition to the impacts of PAQ on human health, it can reduce visibility [8], lead to climate change [9,10], and damage buildings [11,12]. 
According to [13], air quality is better in rural areas compared with urban areas, and they attributed this to the likelihood of fewer emission sources such as traffic and industry in rural settlements. In the same vein, the morphology (buildings and developments) of urban areas, urban constituents, differences in vegetation and anthropogenic activities modify the tropospheric part of the atmosphere over cities and can exacerbate PAQ [14]. However, it should be noted that PAQ may not always be attributed to the emission of pollutants into the atmosphere through human activities. According to [15] noted that contributors to PAQ can be grouped into four main categories: natural, area, mobile and major sources. 'Natural' sources include physical disasters such as forest fires, volcanic erosion, dust storms and agricultural burning. 'Area' sources include domestic and commercial cleaning activities, printing shops, and petrol stations. 'Mobile' sources comprise automobiles, cars, railways, airways, and other types of vehicles. 'Major' sources contain the emission of pollutants from power stations and refineries as well as petrochemical, chemical, fertilizer, metallurgical and other industrial plants, and incineration.

Due to the significant health and environmental problems created by PAQ, the need for its mitigation has become clear $[16,17]$. The Sustainable Development Goals (SDGs) include goals, targets and indicators (goals 3, 7 and 11, especially) to address air pollution and improve air quality. Indeed, the United Nations has asserted that clean air is one of the necessities for human health and wellbeing [18,19]. There have been several studies on the assessment of air quality in urban environments in the developing world [20-30] and approaches include the use of automated monitoring stations, computer models and, more recently, earth observation (EO) via satellites [31-33]. However, these are often expensive and require technical skills to operate, maintain and interpret [34,35] and the cost and need for expertise and equipment can restrict their use in an urban environment in the developing world [34,36-38]. Therefore, for many people living in urban areas in developing countries, there may not be adequate measuring instruments available to use on a routine basis [39] and obtaining and sustaining the supply of high-grade air quality data to help identify places at risk and inform interventions to reduce the risk of PAQ remains a major challenge $[40,41]$.

There have been calls to embrace the perceptions of local people regarding PAQ, its causes and mitigation as an additional approach to help in assessing the problem and in decision-making [42,43]. The assumption here is that people who live and work in urban environments may have a 'sense' about the quality of the air they breathe, how it changes over space and time, the main causes and impacts of PAQ and what can be done both by themselves and others to help address the issue $[3,43,44]$. This includes the kind of 'perceived' (i.e., perceptual) indicators (or 'signals') that people may use or find meaningful and based on these, how they feel that PAQ varies over space and time [43,45]. People's attitudes towards PAQ, including the factors that influence their awareness of it and the kind of 'signals' that they use to know whether air is of poor quality, have been explored in the literature [46-48] along with people's views on the impacts of PAQ [49-51] but there has been little work undertaken in cities of the developing world [52]. In particular, little is known about:

i. What are the main perceptual indicators of PAQ employed by city residents?

ii. What people think are the main causes of PAQ?

iii. What people think can be done to address PAQ?

iv. Who should be primarily responsible for addressing PAQ, including changes in behaviour?

In addition to these questions, little is known from the developing world about how the answers to these questions may differ between social groups (i.e., groups based on gender, age, income, education) [53,54]. For example, regarding point $i$, the work of [53] found that younger people have more awareness of PAQ than older people, while men have lower awareness than women. In addition, Ref. [55] noted that women were more aware of PAQ before and during the COVID-19 pandemic than were men. In terms of what people think are the main causes of PAQ (point ii), what can be done about PAQ (point iii) and who should be the primary agents for implementing the changes (point iv) it is not 
inconceivable that these may vary between cities depending on a number of factors. For example, in terms of point iv, some countries have strong centralised models of governance while others have a federal system, where power, at least in theory, is devolved to smaller administrative units such as states. In Nigeria, for example, there is a federal capital city (Abuja) and 36 state capital cities. Individual states do have some degree of power to monitor air quality and implement change, but legislations for monitoring and controlling air quality are set at the federal level and the key agencies that are tasked to deal with the issue are those funded and mandated by the federal government. However, states can also play a role, and Table 1 sets out some of the interventions to reduce short-lived climate pollutants in Nigeria [56].

Table 1. Focal points of the national action plan to reduce short-lived climate pollutants (SLCP) in Nigeria.

\begin{tabular}{|c|c|}
\hline Source Sector & SLCP Abatement Measures \\
\hline Transport & $\begin{array}{l}\text { - } \\
\text { - } \\
\text { - } \\
\text { - } \\
\text { Intronewal of urban of CNG Buses in Nigeria. } \\
\text { Elimination of high emitting vehicles that do not meet vehicle } \\
\text { emission standards. } \\
\text { - Reduction of vehicle journeys by car through transport modal shifts. }\end{array}$ \\
\hline Residential & $\begin{array}{l}\text { Increase in population using modern fuels for cooking (LPG, } \\
\text { electricity, kerosene, biogas, solar cookers). } \\
\text { Replacement of traditional biomass cookstoves with more efficient } \\
\text { improved biomass stoves. } \\
\text { - Elimination of kerosene lamps. }\end{array}$ \\
\hline Oil and Gas & $\begin{array}{ll}\text { - } & \text { Elimination of gas flaring. } \\
\text { - } & \text { Fugitive emissions/leakages control. } \\
\text { Methane leakage reduction. }\end{array}$ \\
\hline Industry & - Improved energy efficiency in industrial sector \\
\hline Waste Management & $\begin{array}{l}\text { - } \quad \text { Reduction of methane emissions and open burning of waste at open } \\
\text { dumpsites through the adoption of digesters at dumpsites. } \\
\text { - } \quad \text { Septic sludge collection. } \\
\text { - } \quad \text { Sewerage systems and municipal wastewater treatment plants. }\end{array}$ \\
\hline Agriculture & $\begin{array}{l}\text { - Increased adoption of intermittent aeration of rice paddy fields (AWD). } \\
\text { - } \quad \text { Reduce open-field burning of crop residues. } \\
\text { - }\end{array}$ \\
\hline Power (Energy) & $\begin{array}{l}\text { - } \quad \text { Expansion of national electricity coverage. } \\
\text { - Increase share of electricity generated in Nigeria from renewables. }\end{array}$ \\
\hline HFCs & - $\quad$ Elimination of HFC consumption. \\
\hline
\end{tabular}

Source: CCAC and UNEP (2018).

However, in such a multi-tiered governance structure, are people's views about suitable interventions and primary responsibilities framed by their location within the structure? It is known, for example, that people can often have more trust in local governance structures and agencies compared to national ones [57,58], although there are notable exceptions to this, for example in China [59]. Over-laying this sense of distance to decisionmaking, Nigeria also has hundreds of ethnic groups each with their own language, history and culture. Hence, it seems reasonable to ask whether people living in Abuja have a 
different view as to the assessment and control of PAQ compared to those living in a state capital? Do residents in Abuja have more trust in the federal government and its agencies than do those living in a state capital city?

The research reported here was designed to investigate residents' perceptions of PAQ in Nigeria's capital city Abuja (one of the world's fastest-growing cities [60]) and Enugu the state capital of Enugu State, Nigeria. The latter was chosen as being one of the oldest state capitals in the country, and indeed was originally the capital of the Eastern Region when Nigeria gained its independence from Britain in 1960 and was also the de facto capital city of Biafra; the name adopted by the Eastern Region (now South East and South-South) when the nation tried to secede from Nigeria in the late 1960s and which spurred the Civil War in the country. Abuja is a city inhabited by peoples from all over the country and thus is multi-ethnic, while Enugu is less ethnically diverse with the population largely comprising the Igbo ethnic group.

The research employed a questionnaire-based survey which aimed to explore the perceptual indicators of PAQ used by residents in the two cities, their perceptions of the sources of PAQ, views on what should be the control measures for PAQ and who should take foremost responsibility for implementing such control measures. In addition, the research sought to explore whether these views were also influenced by demographic factors such as gender, age, income, education, primary occupation and main mode of transport of respondents.

\section{Materials and Methods}

\subsection{Research Locations}

\subsubsection{Nigeria}

Nigeria is located on the West African coast bordered by Benin, Niger, Chad and Cameroon (Figure 1). The country is a federation comprising 36 autonomous states, with the capital city, Abuja, located in the Federal Capital Territory (FCT) at the geographical center of the country. Each of the 36 states has its own capital city, elected governor, and assembly while the FCT is governed by a minister appointed by the President. The population of Nigeria is estimated to be 211.4 million people [61] and Nigeria has the third-largest youth population in the world [62]. The average age of Nigerian citizens is low for both males and females; the median age is 18.4 years, with just over half of the population being under 35 . The country is culturally and ethnically diverse, comprising some 250 different ethnic groups and 500 different languages. The most populous groups include the Hausa in the north (23\%), Yoruba in the south west (21\%) and Igbo (Ibo) in the south-east $(18 \%)$. The remainder is largely made up of the Ijaw $(10 \%)$, Fulani $(6 \%)$, Kanuri (4\%), Ibibio (3.5\%), Tiv (2.5\%), and others (12\%). In general, urban dwellers have higher levels of education than those who live in rural areas; $69 \%$ of urban dwellers have secondary or higher levels of education while only $37 \%$ of rural dwellers do [63]. In Nigeria, $63 \%$ of people living in the rural areas are poor compared with $42 \%$ for urban areas, and because of this disparity, there has been significant and sustained migration from rural areas to the cities [64]. 


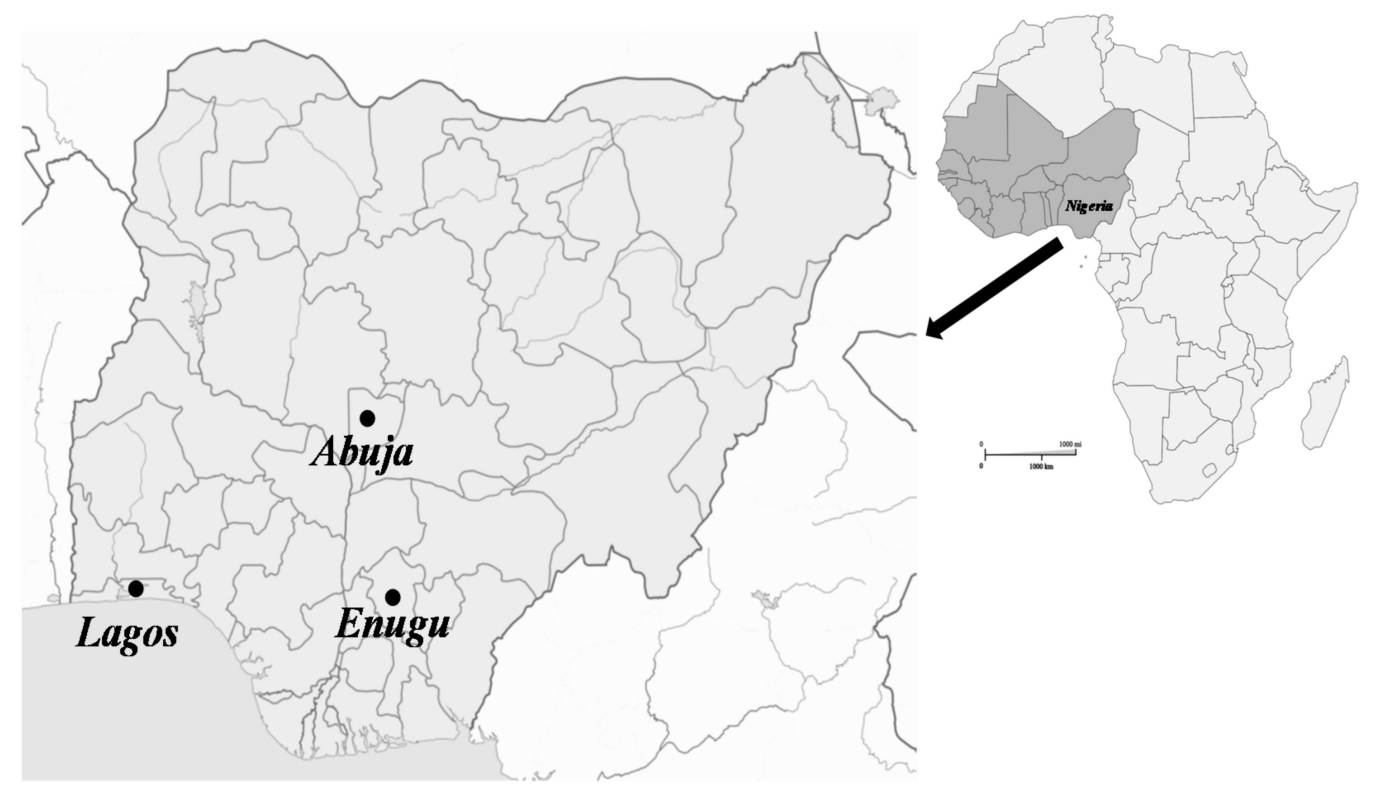

Figure 1. Locations of Abuja (federal capital) and Enugu (state capital of Enugu State) in Nigeria, West Africa.

\subsubsection{Abuja and Enugu}

Abuja is in the Federal Capital Territory (FCT) which is geographically located in the middle of Nigeria (Figure 1). Abuja was regarded by the United Nations in 2010 as the fastest growing city in the world, with an increase in the 10 years between 2000 and 2010 of 140\% [65]. More recently, the country's National Bureau for Statistics in 2016 estimated the population of FCT to be 3,564,126 using the annual growth rate of $9.3 \%$ from the 2006 population census with Abuja city having a projected population of approximately 1,967,500 [66]. Abuja officially became Nigeria's capital in December 1991 and was designed to replace the densely populated city of Lagos in the southwest as the administrative and political hub of the country. The development of Abuja began in the 1970s and it is a planned city with wide, parallel roads and districts specifically set aside for housing, government, commercial activities, etc. The economy of Abuja is dominated by financial services, retail and real estate, and the city has little in the way of manufacturing although, the Seven-Up Bottling Company and the Nigerian Bottling Company makers of Coca Cola are situated in Idu industrial area. As Abuja is the federal capital, the population tends to be ethnically diverse; indeed, the central location of the city in Nigeria was meant to help promote such diversity [67].

Enugu is the capital of Enugu State, located in the south-eastern part of Nigeria (Figure 1). Enugu sits at an altitude of approximately $223 \mathrm{~m}$ on the Udi escarpment, and is situated in the tropical rain forest zone with a derived savannah $[68,69]$. The population of Enugu was estimated to be 773,000 in 2019 [70], and it is an ancient city, existing long before Nigeria became independent in 1960, and is not a 'planned' city in the same way as Abuja. There is no formal zoning, and the road system has evolved as the city has grown and industrial and commercial activities are typically mixed within residential areas. The result is that many roads are narrow, some are unpaved and lack adequate drainage, and they wind their way through the city. This has resulted in traffic jams that commonly occur in some areas of the city mostly during peak periods between Monday and Saturday. Furthermore, Enugu has many markets and manufacturing plants, including Ogbete Main market, New Market, many retail shops, ANAMMCO (Anambra Motor Manufacturing Company), Innoson Group, Juhel Pharmaceutical, Nigeria Breweries, Dalex Paints. Emene industrial layout houses many manufacturing industries in Enugu. In contrast to Abuja, the population of Enugu is less ethnically diverse and dominated by the Igbo ethnic group [71]. 
As with most Nigerian cities, both Abuja and Enugu have high levels of traffic (cars, buses, trucks) and neither have public transport systems in the form of a train or metro [72,73]. There are no official statistics about traffic density in the two cities, but according to a [74] report, 25,415 driving licenses were produced in Abuja and only 9073 in Enugu in the first quarter of 2018. Both cities have the same issues of intermittent power supply seen throughout the country, and many private dwellings and companies own generators (typically diesel-powered) which are used to support lighting and air conditioning as well as manufacturing. The consumptions of energy in Abuja and Enugu are 955,224,978.33 kWh and 594,915,911.00 kWh, respectively, in July 2018 [75]. In Abuja, $26 \%$ and $66 \%$ of residents manage their waste by burning and dumping in their vicinity, respectively [76] while in Enugu it is $28 \%$ and $67 \%$ [77]. As with all urban areas in Nigeria, both cities can be subjected to smoke from bush-burning especially at the start of the dry season as farmers clear their land for planting [78,79]. In addition to the human-made sources of PAQ, there is a natural contributor that arises because of the Harmattan or dry season dust which normally lasts between November and January as the prevailing winds change and bring dust from the Sahel and Sahara further south [5]. As Abuja is further north than Enugu the Harmattan is often claimed to be heavier in Abuja due to its more northerly location than Enugu.

The federal nature of government in Nigeria means that Enugu will have some level of control over assessing and monitoring air quality, but federal agencies are also involved, and while these are headquartered in Abuja, they will have offices in all state capitals. According to [80], the government has mandated the organizations in Table 2 for monitoring and regulating air quality in the country.

Table 2. Organisations responsible for the monitoring and control of air quality in Nigeria.

\section{Organisation}

Federal Ministry of Environment

- $\quad$ NESREA (National Environmental Standards Regulations and Enforcement Agency).

NIMET (Nigerian Meteorological Agency).

State ministries of environment.

\section{Mission} Date of Establishment

Established to ensure environmental protection, natural resources conservation and sustainable development. These include responsibilities for environmental and air quality monitoring and regulatory activities.

To observe, collate, collect, process and disseminate all meteorological data and information within and outside Nigeria.

FMEnv (June 1999)

NESREA (30 July 2007)

Subsidiaries of the federal ministry of environment in the 36 states including the FCT that monitor and ensure a better environment including cleaner air.

\section{Research institutions.}

- Universities

National Space Research and Development Agency (NASRDA).

- $\quad$ Centre for Atmospheric Research (CAR).
Research on the environment including air quality.

Monitoring the environment using satellite. CAR is the Research and Development activity Centre of NASRDA that is committed to research and 5 May 1999 capacity building in atmospheric sciences.

\subsection{Sample Participants and Demographics}

The research involved a questionnaire-based study of participants in Abuja (137 respondents) and Enugu (125 respondents). Respondents had to be a resident of the city as well as work there, and the sample was stratified to ensure that it had adequate representation in terms of gender, age and education that reflected the wider population profile in the two cities. All respondents were at least 18 years old to comply with the ethical requirement of the University of Surrey. The demographic profiles of respondents in the two cities are shown in Table 3. The result of the stratification was an approximately $50: 50$ gender balance in Enugu and $55.5 \%$ and $44.5 \%$ in Abuja. Young adults (youth) from 25-34 years old (note: at the time of the research the term 'youth' was used by the Nigerian 
government for the 25-34 years old demographic [81] were the most represented age group in the study. The largest single groups of income earners were those earning more than $\$ 245(\mathrm{~N} 100,000)$ per month in Abuja (41\% of respondents) whereas it was more than $\$ 125$ $(\mathrm{N} 51,000)$ per month income earners in Enugu (31\% of respondents). Respondents with bachelor's degrees or equivalent were the largest groups in terms of highest education qualification, $43 \%$ and $62 \%$ in Abuja and Enugu, respectively, although a further $35 \%$ of Abuja respondents have a master's degree or its equivalent compared to $14 \%$ in Enugu. Most of the participants' employment was based on a monthly salary ( $84 \%$ and $76 \%$, respectively). The main mode of transport for the participants in Abuja is by personal car $(41 \%)$ and car taxi $(23 \%)$, while in Enugu it was by public bus ( $42 \%)$ and bike (tricycle) taxi $(26 \%)$.

Table 3. Demographic characteristics of the participants including the number of respondents in the groups (percentage of the sample in parentheses).

\begin{tabular}{|c|c|c|}
\hline Characteristics & Abuja $(N=137)$ & Enugu $(\mathrm{N}=125)$ \\
\hline \multicolumn{3}{|l|}{ Gender of respondents } \\
\hline Male & $76(55 \%)$ & $63(50 \%)$ \\
\hline Female & $61(45 \%)$ & $62(50 \%)$ \\
\hline \multicolumn{3}{|l|}{ Age of respondents (cohort) } \\
\hline $18-34$ & $61(45 \%)$ & $60(45 \%)$ \\
\hline 35 and over & $76(55 \%)$ & $65(55 \%)$ \\
\hline \multicolumn{3}{|c|}{ Average monthly income (N) of respondents } \\
\hline No income & $12(9 \%)$ & $13(10 \%)$ \\
\hline Under 10,000 & $7(5 \%)$ & $5(4 \%)$ \\
\hline $11,000-30,000$ & $15(11 \%)$ & $21(17 \%)$ \\
\hline $31,000-50,000$ & $23(17 \%)$ & $29(23 \%)$ \\
\hline $51,000-100,000$ & $24(18 \%)$ & $39(31 \%)$ \\
\hline Over 100,000 & $56(40 \%)$ & $18(15 \%)$ \\
\hline \multicolumn{3}{|c|}{ Highest education qualification of respondents } \\
\hline None & $0(0 \%)$ & $0(0 \%)$ \\
\hline Primary & $1(1 \%)$ & $0(0 \%)$ \\
\hline Secondary & $27(20 \%)$ & $25(20 \%)$ \\
\hline Bachelor/Diploma or equivalent & $59(43 \%)$ & $78(62 \%)$ \\
\hline Master or equivalent & $48(35 \%)$ & $18(15 \%)$ \\
\hline PhD or equivalent & $2(1 \%)$ & $4(3 \%)$ \\
\hline \multicolumn{3}{|l|}{ Main occupation of respondents } \\
\hline Student & $15(1 \%)$ & $13(10 \%)$ \\
\hline Unemployed & $4(3 \%)$ & $7(6 \%)$ \\
\hline Employed (daily wage) & $7(5 \%)$ & $2(2 \%)$ \\
\hline Employed (weekly wage) & $2(1 \%)$ & $1(1 \%)$ \\
\hline Employed (monthly wage) & $84(63 \%)$ & $76(60 \%)$ \\
\hline Self-employed & $17(12 \%)$ & $25(20 \%)$ \\
\hline Housewife & $5(3 \%)$ & $0(0 \%)$ \\
\hline Retired & $3(2 \%)$ & $1(1 \%)$ \\
\hline
\end{tabular}


Table 3. Cont.

\begin{tabular}{lcc}
\hline \multicolumn{1}{c}{ Characteristics } & Abuja (N = 137) & Enugu (N = 125) \\
\hline Main modes of transportation used by respondents & & \\
\hline Walking & $16(12 \%)$ & $5(4 \%)$ \\
\hline Bicycle & $2(1 \%)$ & $0(0 \%)$ \\
\hline Motorcycle & $11(8 \%)$ & $2(2 \%)$ \\
\hline Car taxi & $31(23 \%)$ & $10(8 \%)$ \\
\hline Tricycle taxi (Keke) & $6(4 \%)$ & $33(26 \%)$ \\
\hline Motorcycle taxi (Okada) & $7(5 \%)$ & $1(1 \%)$ \\
\hline Public bus & $8(6 \%)$ & $52(41 \%)$ \\
\hline Train & $0(0 \%)$ & $22(18 \%)$ \\
\hline
\end{tabular}

\subsection{Data Collection}

Data collection took place between 28 October 2020 and 31 March 2021, covering a period that spans the end of the rainy season (October), the dry season, and the beginning of the rainy season (March) in the study areas. Due to the pandemic, which was at its peak during the early period of data collection, the survey was conducted online using the Qualtrics-XM Platform. In the later stages of the timeframe (when social distancing was reduced) hard copies of the questionnaire were also distributed to help those who did not have access to an electronic device. The study involved the recruitment and briefing of eight field assistants (four per city) to serve as helpers in carrying out the study. Monetary incentives were provided to the assistants (approx. \$5600 (US\$14) per assistant over the

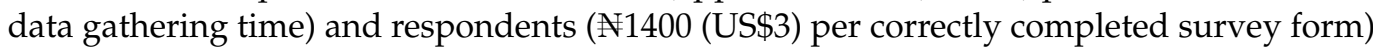
to secure and reflect thanks for their participation.

Respondents were selected by the field assistants under the guidance of the research team, and careful monitoring ensured that the respondents matched the stratification noted above. The pandemic created some limitations on the choice of respondents within the various demographic categories set out in Table 3. The respondents who responded online were called regularly or visited to ensure that they completed the questionnaires. Those who are not familiar with the internet were helped to get internet access. Those respondents using hard copies of the questionnaire were allowed to complete them at a convenient time and an agreed collection time was scheduled. All the respondents in Enugu (100\%) are of the Igbo ethnic group while the respondents in Abuja are more ethnically diverse (Tiv 16\%, Yoruba $17 \%$, Igbo $20 \%$, Hausa $13 \%$, Fulani 7\%, Edo 7\%, Idoma $6 \%$, Igala 5\%, Efik $4 \%$, Ibibio $2 \%$, Gbagyi 1\%, Ijaw 1\%, Eggon 1\%, Berom 1\%) which is not surprising given the status of Abuja as the country's capital city and the location at the centre of Nigeria was chosen to encourage the development of a more diverse population.

\subsection{Questionnaire Design and Statistical Analysis}

The questionnaire (Appendix A) was structured to assess the responses of six demographics (gender, age, income, education, occupation, and transportation) to the perceived indicators of PAQ, sources of PAQ, interventions to control PAQ, and who should take primary responsibility for interventions. Responses to the questions were based on the use of the Likert scales (scores from 1 to 5 ) shown in Table 4. Statistical analysis was carried out using the software SPSS ${ }^{\circledR}$ version 28.0. Descriptive statistics (counts) were used to present the characteristics of the participants, and the Kruskal-Wallis and Hochberg post hoc tests (all non-parametric) were used to assess differences between groups $[82,83]$. To compare responses from Abuja with those from Enugu, the mean scores for indicators, sources, control measures and primary responsibility for the two cities were tested for association using the Spearman Rank Correlation Coefficient. 
Table 4. Summary of the main survey questions and the Likert scale answers.

\begin{tabular}{lccccc}
\hline \multicolumn{1}{c}{ Questions } & \multicolumn{5}{c}{ Likert Scale Scores } \\
\hline Perceived Indicators of PAQ & $\mathbf{1}$ & $\mathbf{2}$ & $\mathbf{3}$ & $\mathbf{4}$ & $\mathbf{5}$ \\
\hline Sources of PAQ & most used & used & neutral & rarely used & least used \\
\hline Effectiveness of control measures for PAQ & $\begin{array}{c}\text { extremely } \\
\text { effective }\end{array}$ & $\begin{array}{c}\text { very } \\
\text { effective }\end{array}$ & $\begin{array}{c}\text { moderately } \\
\text { effective }\end{array}$ & $\begin{array}{c}\text { slightly } \\
\text { effective }\end{array}$ & strongly disagree \\
\hline $\begin{array}{l}\text { Organisation/group who should take } \\
\text { primary responsibility for controlling PAQ }\end{array}$ & strongly agree & agree & neutral & disagree & strongly disagree \\
\hline
\end{tabular}

\section{Results}

\subsection{Perceptual Indicators of $P A Q$}

The results for the use of perceptual indicators of PAQ in Abuja and Enugu are shown in Figure 2a,b. The Spearman rank correlation for the mean indicator scores from Abuja and Enugu is $0.7(p<0.05)$. This similarity in the respondents' overall mean scores (both ranging between approx. 1.8 and 3) suggest that there is little difference between respondents from the two cities in the overall strength of views regarding the importance given to the range of indicators. The mean ratings indicate that most of the indicators were of some use in the perception of PAQ in both Abuja and Enugu, with only a couple of indicators in both cities rated as 'neutral' and no indicators rated as rarely used or not used at all. In Abuja, the post hoc test identified three groups (horizontal lines in Figure 2a) of indicators without a significant difference between them. Group 1 comprises the most frequently used indicators namely dust in the air, smoke, odour, dirt on skin and clothes and dirt on surfaces such as buildings. Group 2 comprised the indicators of smoke, odour and dirt on skin and clothes, dirt on surfaces such as buildings, visibility, and sneezing/coughing; and Group 3 comprised of watery/irritated eyes and skin irritation. Dust in the air is the most commonly employed means by which people perceive the quality of air in Abuja, but Group 1 in Figure 2a comprises some indicators closely related to dust in the air (i.e., smoke, dust on skin/clothes, dust on surfaces). Skin irritation is ranked as the least used indicator of PAQ in Abuja. In Figure 2b, the indicators for Enugu fell into four groups but, interestingly, the three most commonly used indicators (dust in the air, smell/odour and smoke) are the same in both cities, albeit in a slightly different order between the cities. As in Abuja, the least used indicator in Enugu was skin irritation. Therefore, the results show that respondents from the two cities most frequently employed dust particles in the air, smoke and odour as their main means of perceiving PAQ. In the 'middle ground' indicators, there are differences between the two cities in their specific ranking order, although these are usually only of two places in the order suggesting relatively minor local nuances. 


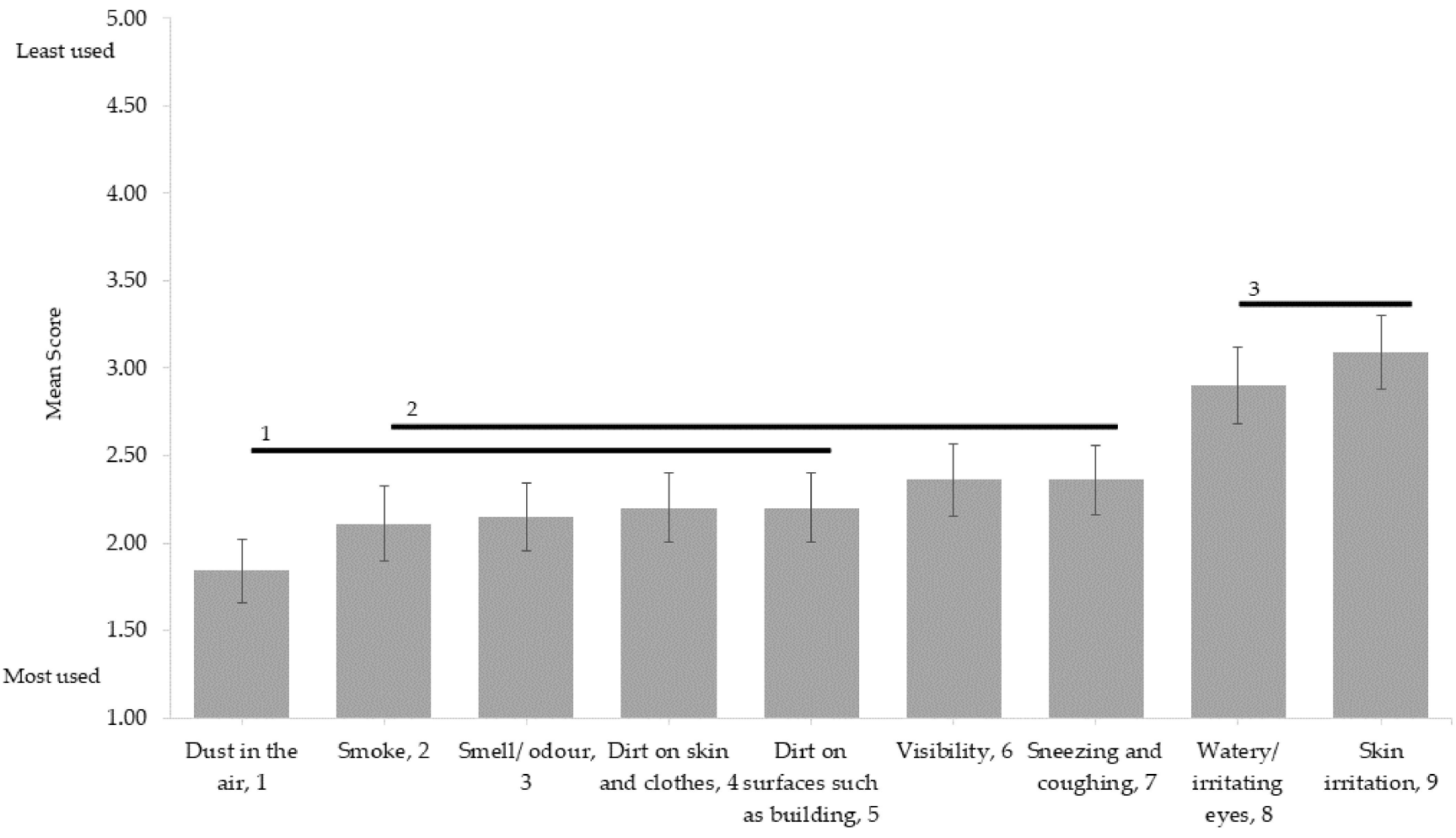

Perceptual indicators

(a)

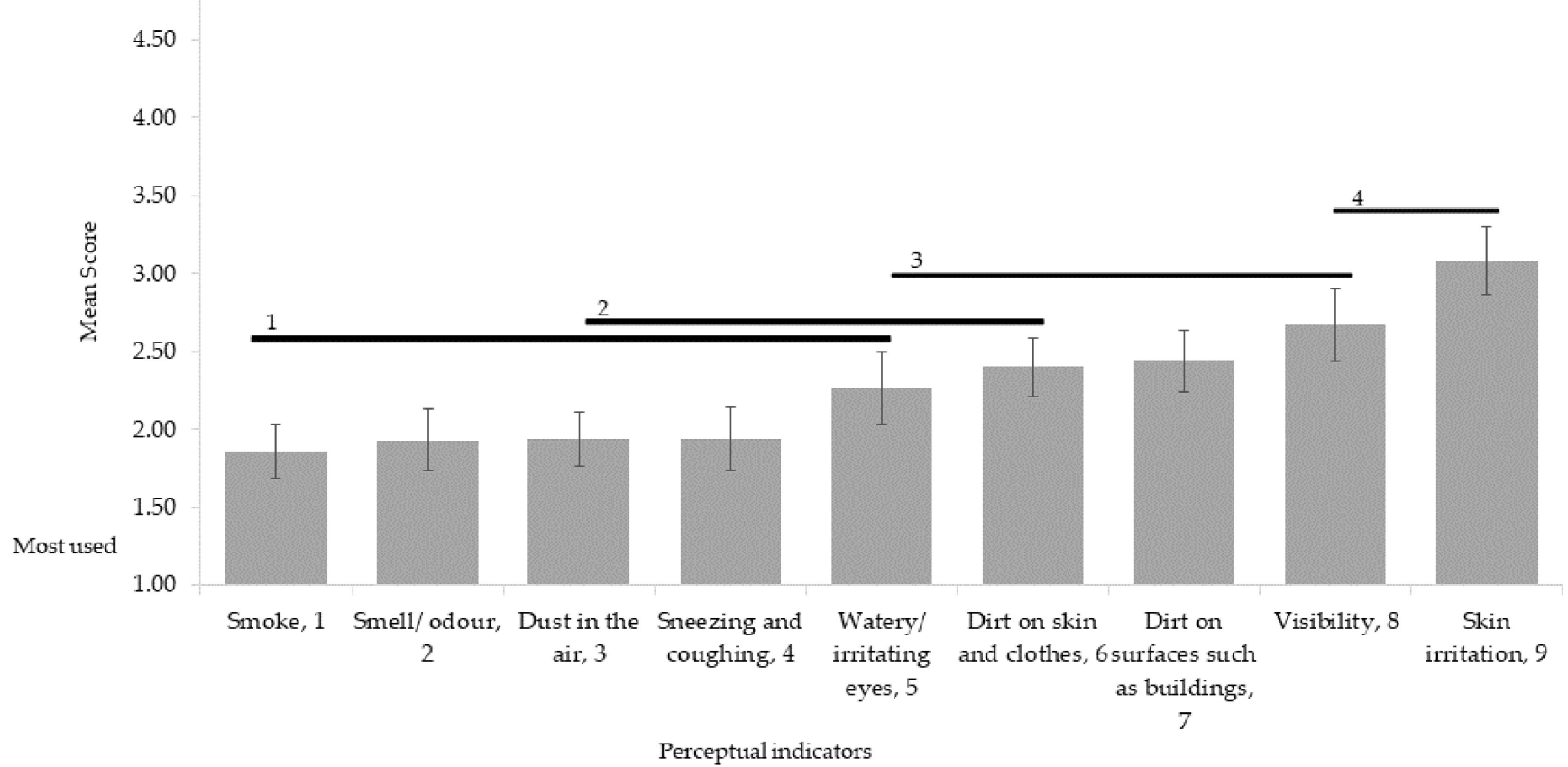

(b)

Figure 2. (a) Perceptual Indicators of PAQ in Abuja. (b) Perceptual Indicators of PAQ in Enugu. Numbers on the horizontal axis are the ranks for the perceptual indicators. Error bars are the $95 \%$ confidence interval for the means. Horizontal bars (and numbers) are the groups identified via the Hochberg post hoc test as significant at $p<0.05$. 
Table 5 presents the results of Kruskal-Wallis tests for differences in scoring the indicators across the various demographic characteristics. Only 4 out of 108 tests in the table yielded significant differences between the scoring of the indicators within the demographic groups. A few significant differences were found with the 'Smell/odour' and the 'Dust particles in the air' indicators within the income demographic in Abuja and 'Dirt on skin and clothes' for gender in Enugu. However, this small and dispersed number of significant associations between the scoring of indicators within the demographic groupings for any of the PAQ indicators in both cities suggests that demographic factors do not have any appreciable influence on the relative scoring of the indicators, i.e., the indicators are perceived to have much the same usage across all the demographics in both cities.

Table 5. Results of the Kruskal-Wallis tests for significant differences within the demographic groups in Abuja and Enugu for the scoring of perceptual indicators of PAQ.

\begin{tabular}{|c|c|c|c|c|c|c|c|}
\hline \multirow{2}{*}{$\begin{array}{l}\text { Perceptual } \\
\text { Indicators }\end{array}$} & \multicolumn{7}{|c|}{ Sample Demographic Characteristics } \\
\hline & Cities & Gender & Age & Income & Education & Occupation & Transportation \\
\hline \multirow{2}{*}{ Visibility } & Abuja & $0.15 \mathrm{~ns}$ & $7.29 \mathrm{~ns}$ & $4.24 \mathrm{~ns}$ & $5.15 \mathrm{~ns}$ & $13.70 \mathrm{~ns}$ & $4.27 \mathrm{~ns}$ \\
\hline & Enugu & $0.27 \mathrm{~ns}$ & $10.22 \mathrm{~ns}$ & $5.53 \mathrm{~ns}$ & $4.75 \mathrm{~ns}$ & $4.96 \mathrm{~ns}$ & $6.02 \mathrm{~ns}$ \\
\hline \multirow{2}{*}{ Smell/odour } & Abuja & $0.06 \mathrm{~ns}$ & $5.76 \mathrm{~ns}$ & $16.30 * *$ & $9.10 \mathrm{~ns}$ & $7.50 \mathrm{~ns}$ & $6.16 \mathrm{~ns}$ \\
\hline & Enugu & $0.83 \mathrm{~ns}$ & $7.85 \mathrm{~ns}$ & $4.12 \mathrm{~ns}$ & $1.66 \mathrm{~ns}$ & $5.97 \mathrm{~ns}$ & $3.51 \mathrm{~ns}$ \\
\hline \multirow{2}{*}{ Dust particles in the air } & Abuja & $1.17 \mathrm{~ns}$ & $4.16 \mathrm{~ns}$ & 13.07 * & $7.16 \mathrm{~ns}$ & $5.33 \mathrm{~ns}$ & $6.98 \mathrm{~ns}$ \\
\hline & Enugu & $0.00 \mathrm{~ns}$ & $10.22 \mathrm{~ns}$ & $5.94 \mathrm{~ns}$ & $5.74 \mathrm{~ns}$ & $7.48 \mathrm{~ns}$ & $5.07 \mathrm{~ns}$ \\
\hline \multirow{2}{*}{ Dirt on skin/clothes } & Abuja & $1.28 \mathrm{~ns}$ & $8.04 \mathrm{~ns}$ & $5.61 \mathrm{~ns}$ & $4.42 \mathrm{~ns}$ & $8.63 \mathrm{~ns}$ & $4.09 \mathrm{~ns}$ \\
\hline & Enugu & $5.13^{*}$ & $8.89 \mathrm{~ns}$ & $4.64 \mathrm{~ns}$ & $0.88 \mathrm{~ns}$ & $5.16 \mathrm{~ns}$ & 13.57 * \\
\hline \multirow{2}{*}{$\begin{array}{l}\text { Dirt on surfaces e.g., } \\
\text { cars, buildings }\end{array}$} & Abuja & $1.51 \mathrm{~ns}$ & $3.77 \mathrm{~ns}$ & $5.40 \mathrm{~ns}$ & $8.02 \mathrm{~ns}$ & $12.09 \mathrm{~ns}$ & $11.97 \mathrm{~ns}$ \\
\hline & Enugu & $2.96 \mathrm{~ns}$ & $8.99 \mathrm{~ns}$ & $5.93 \mathrm{~ns}$ & $1.80 \mathrm{~ns}$ & $5.01 \mathrm{~ns}$ & $10.98 \mathrm{~ns}$ \\
\hline \multirow{2}{*}{ Smoke } & Abuja & $0.85 \mathrm{~ns}$ & $4.85 \mathrm{~ns}$ & $8.27 \mathrm{~ns}$ & $4.76 \mathrm{~ns}$ & $11.87 \mathrm{~ns}$ & $7.48 \mathrm{~ns}$ \\
\hline & Enugu & $0.58 \mathrm{~ns}$ & $7.37 \mathrm{~ns}$ & $3.58 \mathrm{~ns}$ & $0.88 \mathrm{~ns}$ & $9.02 \mathrm{~ns}$ & $10.94 \mathrm{~ns}$ \\
\hline \multirow{2}{*}{ Sneezing/coughing } & Abuja & $1.22 \mathrm{~ns}$ & $8.48 \mathrm{~ns}$ & $4.26 \mathrm{~ns}$ & $5.69 \mathrm{~ns}$ & $3.21 \mathrm{~ns}$ & $2.64 \mathrm{~ns}$ \\
\hline & Enugu & $0.02 \mathrm{~ns}$ & $7.69 \mathrm{~ns}$ & $2.91 \mathrm{~ns}$ & $3.83 \mathrm{~ns}$ & $10.85 \mathrm{~ns}$ & $4.83 \mathrm{~ns}$ \\
\hline \multirow{2}{*}{ Skin irritation } & Abuja & $0.29 \mathrm{~ns}$ & $2.577 \mathrm{~ns}$ & $3.38 \mathrm{~ns}$ & $2.82 \mathrm{~ns}$ & $3.93 \mathrm{~ns}$ & $4.45 \mathrm{~ns}$ \\
\hline & Enugu & $1.35 \mathrm{~ns}$ & $8.04 \mathrm{~ns}$ & $1.41 \mathrm{~ns}$ & $1.39 \mathrm{~ns}$ & $7.20 \mathrm{~ns}$ & $7.49 \mathrm{~ns}$ \\
\hline \multirow{2}{*}{ Watery and itching eyes } & Abuja & $1.58 \mathrm{~ns}$ & $11.01 \mathrm{~ns}$ & $3.97 \mathrm{~ns}$ & $3.35 \mathrm{~ns}$ & $3.27 \mathrm{~ns}$ & $8.27 \mathrm{~ns}$ \\
\hline & Enugu & $2.93 \mathrm{~ns}$ & $3.99 \mathrm{~ns}$ & $1.16 \mathrm{~ns}$ & $4.62 \mathrm{~ns}$ & $3.02 \mathrm{~ns}$ & $6.57 \mathrm{~ns}$ \\
\hline \multicolumn{8}{|c|}{$\begin{array}{l}* p \leq 0.05 ;{ }^{* *} p \leq 0.01 \\
\text { significant differences in } \\
\text { 3.2. Sources of } P A Q\end{array}$} \\
\hline \multicolumn{8}{|c|}{$\begin{array}{l}\text { The results for the perceived sources of PAQ in Abuja and Enugu are shown in } \\
\text { Figure 3a,b. The Spearman rank correlation for the mean scores of PAQ sources from } \\
\text { Abuja and Enugu is } 0.931 \text { ( } p<0.001) \text {, which suggests that the broad pattern in the ranking } \\
\text { of PAQ sources is the same for the two cities. In both cities, the biggest contributors } \\
\text { (Group 1) to PAQ are broadly the same and comprise bush fires, manufacturing, waste } \\
\text { burning, generators and manufacturing, although the order is slightly different. Similarly, } \\
\text { the least important sources are also alike and comprise cooking, rail and air transport and } \\
\text { dry cleaning. }\end{array}$} \\
\hline
\end{tabular}




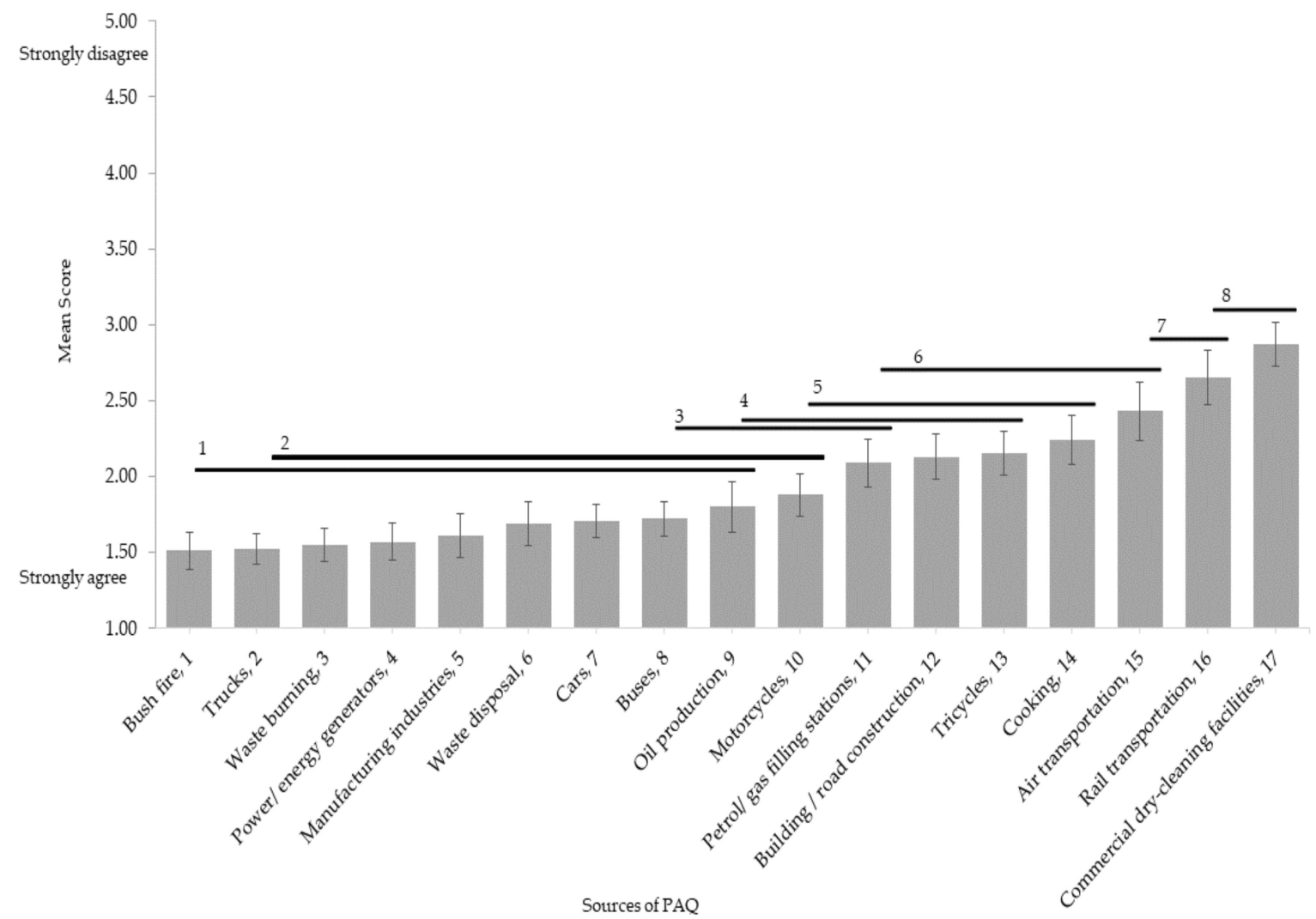

(a)

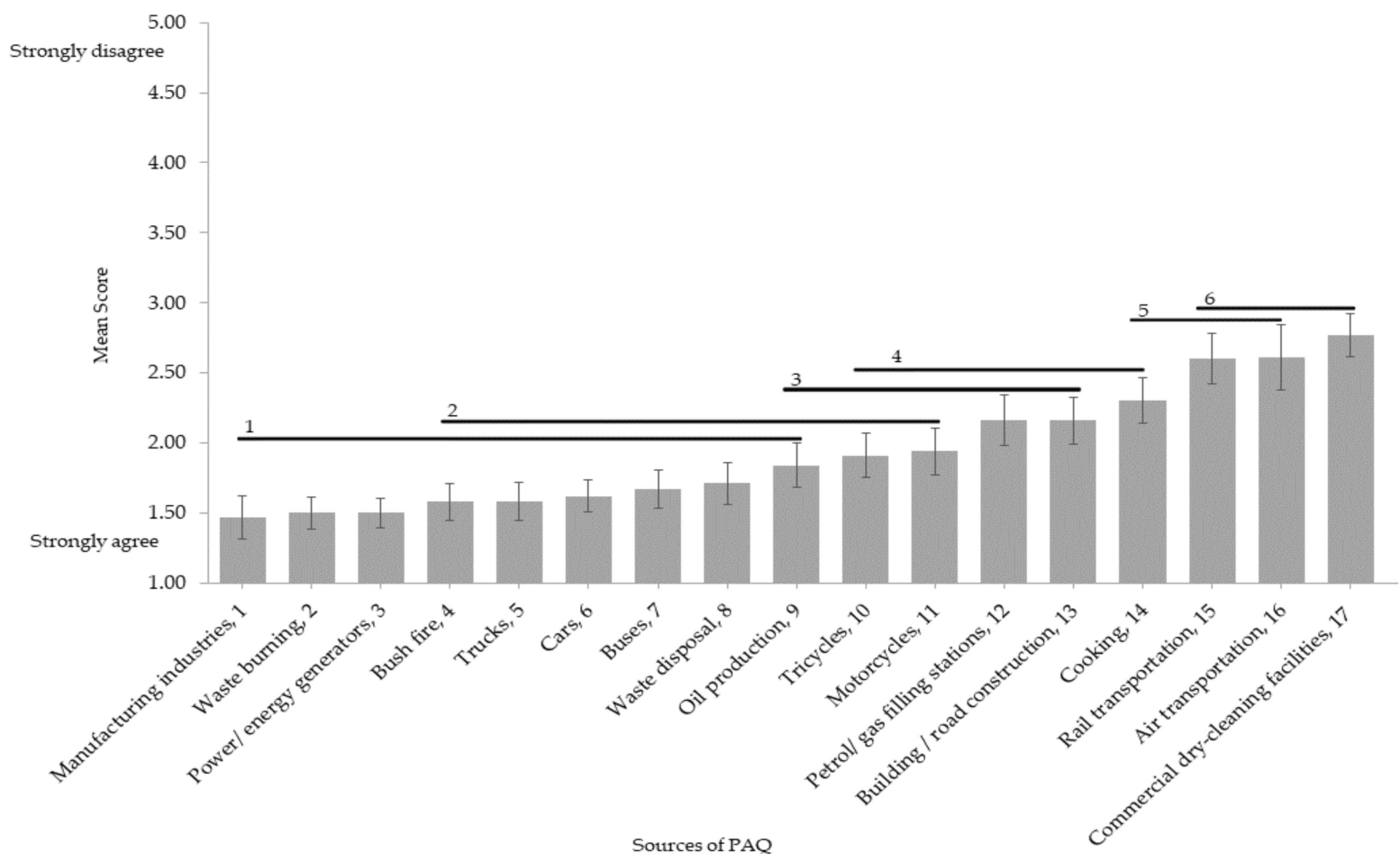

(b)

Figure 3. (a) Residents' perception of sources of PAQ in Abuja. (b) Residents' perception of sources of PAQ in Enugu. Numbers on the horizontal axis are the ranks for the perceptual indicators. Error bars are the $95 \%$ confidence interval for the means. Horizontal bars (and numbers) are the groups identified via the Hochberg post hoc test as significant at $p<0.05$. 
The results of the Kruskal-Wallis tests designed to explore differences between demographic groups in their tanking of the sources of PAQ are shown in Table 6. As with the indicators in Table 5, the results in Table 6 show the majority of tests for differences in perceived PAQ sources between demographics to be non-significant. This suggests that most of the demographic groups have a similar scoring for the various sources of PAQ. However, there were some 20 significant differences in Table 6 and the largest number of these were found in Enugu (16 out of the 20 significant associations), especially with gender, age and income. In both cities, differences in education, occupation and main transportation used by respondents had little effect on their scoring of sources. Of the 20 results in Table 6 that were significant, the pattern is a complex one with no clear match between respondents from the two cities. For example, 7 of the 20 statistically significant results were associated with gender differences but the pattern was not the same for the two cities. In Abuja, the results suggest that while males perceive power generators as PAQ sources more than do females, females perceived waste disposal to be a bigger source of PAQ than did males. In Enugu, four of the sources (cars, buses, trucks and manufacturing industries) are mainly seen by men as sources of PAQ while more women perceive motorcycles as an important PAQ source than do men. Nonetheless, it would seem that there is more agreement between the views of the demographic groups with regard to sources of PAQ than there are differences.

\subsection{Control Measures for $P A Q$}

The results for the control measures that should be adopted to address PAQ in Abuja and Enugu are shown in Figure 4a,b. The Spearman rank correlation for the mean scores of PAQ control measures PAQ from Abuja and Enugu is $0.914(p<0.001)$, which suggest many similarities in scoring between the respondents of the two cities. The top two control measures rated most highly by Abuja respondents (Figure 4a)-proper waste disposal and incineration and avoiding bush burning-are the same as those identified by the Enugu sample (Figure $4 \mathrm{~b}$ ), while the least important control measure in both cities is the reduction in air travel. In between these extremes, the scoring of various control measures does vary across the two cities, but the broad pattern is similar.

In terms of differences in control measures between the demographic groups (Table 7), there were relatively few (8) significant differences regarding gender, income, occupation and main mode of transport, and there was no clear pattern in these between the two cities. This suggests that, in terms of these demographic factors, there was much more agreement than difference in view. However, the one notable exception was with age in Enugu and these results are set out in more detail in Table 8. For almost all the control measures the younger demographic rated their importance higher than did the older demographic. The only control measures that did not have a statistically significant difference between the age groups in Enugu were a parking charge for vehicles and a reduction in air travel. The same pattern in terms of age was not seen in Abuja. Indeed, in that city, none of the control measures had a statistically significant difference between the age groups. 
Table 6. Kruskal-Wallis test results for demographics and sources of poor air quality (PAQ) for Abuja and Enugu.

\begin{tabular}{|c|c|c|c|c|c|c|c|}
\hline Sources of PAQ & Cities & Gender & Age & Income & Education & Occupation & Transportation \\
\hline \multirow{2}{*}{ Air transportation } & Abuja & $3.37 \mathrm{~ns}$ & $1.486 \mathrm{~ns}$ & $6.211 \mathrm{~ns}$ & $5.772 \mathrm{~ns}$ & $7.701 \mathrm{~ns}$ & $7.729 \mathrm{~ns}$ \\
\hline & Enugu & $2.580 \mathrm{~ns}$ & $2.725 \mathrm{~ns}$ & $15.887^{* *}$ & $8.347^{*}$ & $2.816 \mathrm{~ns}$ & $9.393 \mathrm{~ns}$ \\
\hline \multirow{2}{*}{ Cars } & Abuja & $1.172 \mathrm{~ns}$ & $6.804 \mathrm{~ns}$ & $3.696 \mathrm{~ns}$ & $1.042 \mathrm{~ns}$ & $6.092 \mathrm{~ns}$ & $8.464 \mathrm{~ns}$ \\
\hline & Enugu & $8.415^{* *}$ & $5.942 \mathrm{~ns}$ & $7.383 \mathrm{~ns}$ & $2.622 \mathrm{~ns}$ & $5.661 \mathrm{~ns}$ & $8.512 \mathrm{~ns}$ \\
\hline \multirow{2}{*}{ Buses } & Abuja & $0.784 \mathrm{~ns}$ & $14.992 *$ & $4.543 \mathrm{~ns}$ & $0.569 \mathrm{~ns}$ & $4.785 \mathrm{~ns}$ & $9.180 \mathrm{~ns}$ \\
\hline & Enugu & $6.435^{*}$ & $8.372 \mathrm{~ns}$ & $5.905 \mathrm{~ns}$ & $3.03 \mathrm{~ns}$ & $3.278 \mathrm{~ns}$ & $3.411 \mathrm{~ns}$ \\
\hline \multirow{2}{*}{ Trucks } & Abuja & $0.326 \mathrm{~ns}$ & $9.128 \mathrm{~ns}$ & $2.618 \mathrm{~ns}$ & $1.831 \mathrm{~ns}$ & $7.196 \mathrm{~ns}$ & $9.918 \mathrm{~ns}$ \\
\hline & Enugu & $4.969 *$ & $5.478 \mathrm{~ns}$ & $8.516 \mathrm{~ns}$ & $0.964 \mathrm{~ns}$ & $5.805 \mathrm{~ns}$ & $4.305 \mathrm{~ns}$ \\
\hline \multirow{2}{*}{ Motorcycles } & Abuja & $0.192 \mathrm{~ns}$ & $3.657 \mathrm{~ns}$ & $6.692 \mathrm{~ns}$ & $2.292 \mathrm{~ns}$ & $7.038 \mathrm{~ns}$ & $1.840 \mathrm{~ns}$ \\
\hline & Enugu & $10.004^{* *}$ & 12.842 * & $9.582 \mathrm{~ns}$ & $1.892 \mathrm{~ns}$ & $3.548 \mathrm{~ns}$ & $4.956 \mathrm{~ns}$ \\
\hline \multirow{2}{*}{ Tricycles } & Abuja & $0.053 \mathrm{~ns}$ & $7.858 \mathrm{~ns}$ & $4.389 \mathrm{~ns}$ & $2.778 \mathrm{~ns}$ & $10.196 \mathrm{~ns}$ & $9.880 \mathrm{~ns}$ \\
\hline & Enugu & $2.597 \mathrm{~ns}$ & $3.992 \mathrm{~ns}$ & $6.332 \mathrm{~ns}$ & $1.456 \mathrm{~ns}$ & $6.177 \mathrm{~ns}$ & $5.031 \mathrm{~ns}$ \\
\hline \multirow{2}{*}{$\begin{array}{l}\text { Power/energy } \\
\text { generators }\end{array}$} & Abuja & $5.548 *$ & $6.094 \mathrm{~ns}$ & $3.895 \mathrm{~ns}$ & $3.084 \mathrm{~ns}$ & $6.045 \mathrm{~ns}$ & $9.459 \mathrm{~ns}$ \\
\hline & Enugu & $1.174 \mathrm{~ns}$ & $4.327 \mathrm{~ns}$ & $12.426^{*}$ & $7.020 \mathrm{~ns}$ & $11.955 \mathrm{~ns}$ & $3.104 \mathrm{~ns}$ \\
\hline \multirow{2}{*}{ Petrol/gas stations } & Abuja & $0.052 \mathrm{~ns}$ & $5.209 \mathrm{~ns}$ & $1.728 \mathrm{~ns}$ & $2.991 \mathrm{~ns}$ & $3.52 \mathrm{~ns}$ & $10.863 \mathrm{~ns}$ \\
\hline & Enugu & $0.196 \mathrm{~ns}$ & $7.732 \mathrm{~ns}$ & $5.163 \mathrm{~ns}$ & $1.783 \mathrm{~ns}$ & $7.238 \mathrm{~ns}$ & $8.532 \mathrm{~ns}$ \\
\hline \multirow{2}{*}{$\begin{array}{l}\text { Manufacturing } \\
\text { industries }\end{array}$} & Abuja & $1.923 \mathrm{~ns}$ & $4.004 \mathrm{~ns}$ & $0.652 \mathrm{~ns}$ & $3.201 \mathrm{~ns}$ & $9.514 \mathrm{~ns}$ & $5.253 \mathrm{~ns}$ \\
\hline & Enugu & $8.842^{* *}$ & 12.591 * & $1.298 \mathrm{~ns}$ & $0.703 \mathrm{~ns}$ & $12.646^{*}$ & $8.785 \mathrm{~ns}$ \\
\hline \multirow{2}{*}{ Oil production } & Abuja & $1.217 \mathrm{~ns}$ & $7.143 \mathrm{~ns}$ & $0.414 \mathrm{~ns}$ & $4.204 \mathrm{~ns}$ & $9.684 \mathrm{~ns}$ & $7.362 \mathrm{~ns}$ \\
\hline & Enugu & $3.961 \mathrm{~ns}$ & $7.358 \mathrm{~ns}$ & $11.003 \mathrm{~ns}$ & $5.628 \mathrm{~ns}$ & $8.559 \mathrm{~ns}$ & $6.575 \mathrm{~ns}$ \\
\hline \multirow{2}{*}{ Cooking } & Abuja & $0.042 \mathrm{~ns}$ & $5.513 \mathrm{~ns}$ & $5.451 \mathrm{~ns}$ & $4.255 \mathrm{~ns}$ & $8.049 \mathrm{~ns}$ & $3.760 \mathrm{~ns}$ \\
\hline & Enugu & $0.142 \mathrm{~ns}$ & $16.798^{* *}$ & $5.734 \mathrm{~ns}$ & $3.808 \mathrm{~ns}$ & $5.831 \mathrm{~ns}$ & $5.482 \mathrm{~ns}$ \\
\hline \multirow{2}{*}{ Bush fire } & Abuja & $0.069 \mathrm{~ns}$ & $5.754 \mathrm{~ns}$ & $4.258 \mathrm{~ns}$ & $1.796 \mathrm{~ns}$ & $4.529 \mathrm{~ns}$ & $8.672 \mathrm{~ns}$ \\
\hline & Enugu & $3.014 \mathrm{~ns}$ & 10.147 ns & 14.971 * & $6.488 \mathrm{~ns}$ & $9.348 \mathrm{~ns}$ & $6.603 \mathrm{~ns}$ \\
\hline \multirow{2}{*}{$\begin{array}{l}\text { Building/road } \\
\text { construction }\end{array}$} & Abuja & $0.460 \mathrm{~ns}$ & $3.784 \mathrm{~ns}$ & $8.784 \mathrm{~ns}$ & $2.194 \mathrm{~ns}$ & $7.106 \mathrm{~ns}$ & $6.427 \mathrm{~ns}$ \\
\hline & Enugu & $2.947 \mathrm{~ns}$ & $2.398 \mathrm{~ns}$ & $5.125 \mathrm{~ns}$ & $0.477 \mathrm{~ns}$ & $5.651 \mathrm{~ns}$ & $9.623 \mathrm{~ns}$ \\
\hline \multirow{2}{*}{ Rail transportation } & Abuja & $0.186 \mathrm{~ns}$ & $5.172 \mathrm{~ns}$ & $4.188 \mathrm{~ns}$ & $2.658 \mathrm{~ns}$ & $3.129 \mathrm{~ns}$ & $9.384 \mathrm{~ns}$ \\
\hline & Enugu & $0.419 \mathrm{~ns}$ & $6.26 \mathrm{~ns}$ & 2.373 & $1.618 \mathrm{~ns}$ & $5.192 \mathrm{~ns}$ & $1.525 \mathrm{~ns}$ \\
\hline \multirow{2}{*}{ Dry-cleaning facilities } & Abuja & $0.186 \mathrm{~ns}$ & $4.060 \mathrm{~ns}$ & 11.903 * & $6.455 \mathrm{~ns}$ & $3.003 \mathrm{~ns}$ & $9.071 \mathrm{~ns}$ \\
\hline & Enugu & $0.065 \mathrm{~ns}$ & $5.908 \mathrm{~ns}$ & $4.246 \mathrm{~ns}$ & $4.859 \mathrm{~ns}$ & $9.94 \mathrm{~ns}$ & $4.023 \mathrm{~ns}$ \\
\hline \multirow{2}{*}{ Waste disposal } & Abuja & $4.075^{*}$ & $2.288 \mathrm{~ns}$ & $5.368 \mathrm{~ns}$ & $1.205 \mathrm{~ns}$ & $7.069 \mathrm{~ns}$ & $8.680 \mathrm{~ns}$ \\
\hline & Enugu & $2.196 \mathrm{~ns}$ & $10.184 \mathrm{~ns}$ & 11.774 * & $5.894 \mathrm{~ns}$ & 12.964 * & $11.843 \mathrm{~ns}$ \\
\hline \multirow{2}{*}{ Waste burning } & Abuja & $0.017 \mathrm{~ns}$ & $1.294 \mathrm{~ns}$ & $7.369 \mathrm{~ns}$ & $2.010 \mathrm{~ns}$ & $6.665 \mathrm{~ns}$ & $7.659 \mathrm{~ns}$ \\
\hline & Enugu & $3.752 \mathrm{~ns}$ & 14.999 * & $7.77 \mathrm{~ns}$ & $7.741 \mathrm{~ns}$ & $5.406 \mathrm{~ns}$ & $7.089 \mathrm{~ns}$ \\
\hline
\end{tabular}




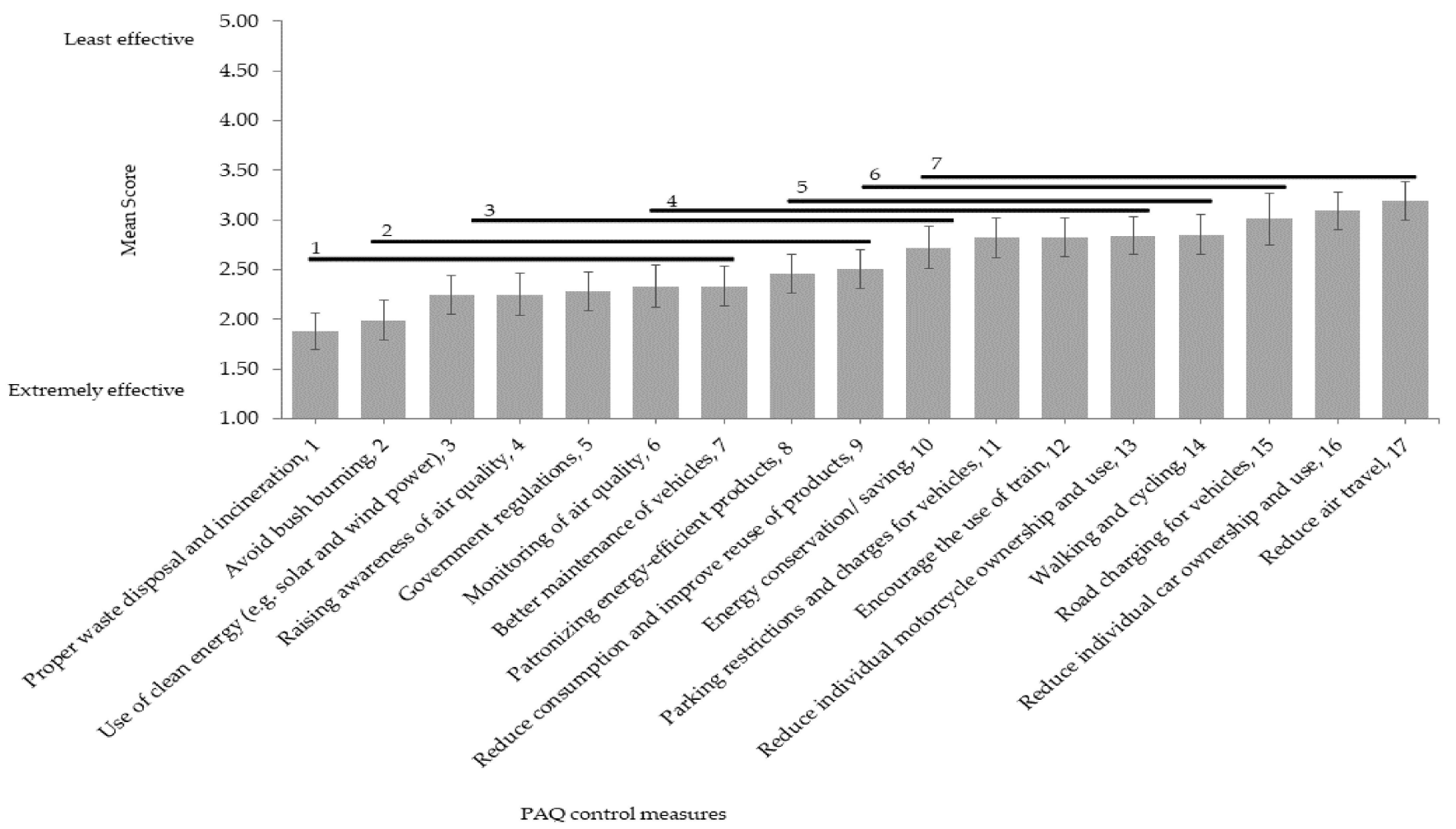

(a)

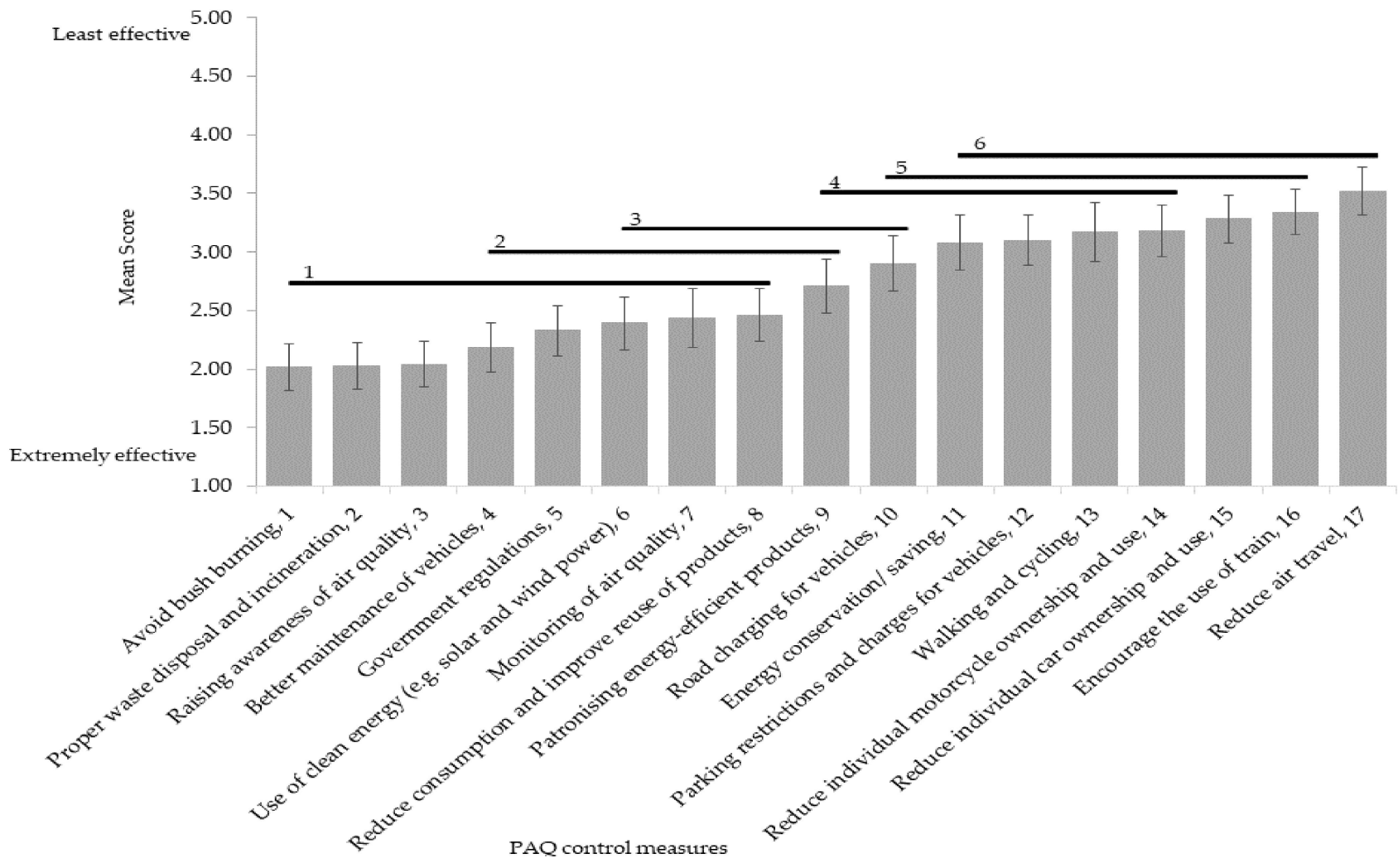

(b)

Figure 4. (a). Residents' perception of control measures for PAQ in Abuja. (b). Residents' perception of control measures for PAQ in Enugu. Numbers on the horizontal axis are the ranks for the perceptual indicators. Error bars are the 95\% confidence interval for the means. Horizontal bars (and numbers) are the groups identified via the Hochberg post hoc test as significant at $p<0.05$. 
Table 7. Kruskal-Wallis test for Demographics (except age) and Control Measures for poor air quality (PAQ) in Abuja and Enugu.

\begin{tabular}{|c|c|c|c|c|c|c|}
\hline Control Measures & Cities & Gender & Income & Education & Occupation & Transportation \\
\hline \multirow{2}{*}{ Energy saving } & Abuja & $0.299 \mathrm{~ns}$ & $6.566 \mathrm{~ns}$ & $5.074 \mathrm{~ns}$ & $6.995 \mathrm{~ns}$ & $10.885 \mathrm{~ns}$ \\
\hline & Enugu & $2.112 \mathrm{~ns}$ & $6.602 \mathrm{~ns}$ & $4.835 \mathrm{~ns}$ & 10.895 ns & $10.423 \mathrm{~ns}$ \\
\hline \multirow{2}{*}{ Reduce car use } & Abuja & $1.952 \mathrm{~ns}$ & $1.142 \mathrm{~ns}$ & $3.751 \mathrm{~ns}$ & $4.192 \mathrm{~ns}$ & $3.629 \mathrm{~ns}$ \\
\hline & Enugu & $0.265 \mathrm{~ns}$ & $4.649 \mathrm{~ns}$ & $0.354 \mathrm{~ns}$ & $10.072 \mathrm{~ns}$ & $8.017 \mathrm{~ns}$ \\
\hline \multirow{2}{*}{ Reduce motorcycle use } & Abuja & $4.036 *$ & $3.686 \mathrm{~ns}$ & $2.598 \mathrm{~ns}$ & $3.653 \mathrm{~ns}$ & $5.439 \mathrm{~ns}$ \\
\hline & Enugu & $0.042 \mathrm{~ns}$ & $5.043 \mathrm{~ns}$ & $3.620 \mathrm{~ns}$ & $8.645 \mathrm{~ns}$ & $5.590 \mathrm{~ns}$ \\
\hline \multirow{2}{*}{ Walking/cycling } & Abuja & $0.177 \mathrm{~ns}$ & $6.784 \mathrm{~ns}$ & $5.129 \mathrm{~ns}$ & $6.717 \mathrm{~ns}$ & $3.126 \mathrm{~ns}$ \\
\hline & Enugu & $2.943 \mathrm{~ns}$ & $1.342 \mathrm{~ns}$ & $3.679 \mathrm{~ns}$ & $11.063 \mathrm{~ns}$ & $13.105 \mathrm{~ns}$ \\
\hline \multirow{2}{*}{ Use of energy efficient products } & Abuja & $1.216 \mathrm{~ns}$ & $1.233 \mathrm{~ns}$ & $5.194 \mathrm{~ns}$ & $4.173 \mathrm{~ns}$ & $4.704 \mathrm{~ns}$ \\
\hline & Enugu & $1.918 \mathrm{~ns}$ & $4.914 \mathrm{~ns}$ & $3.098 \mathrm{~ns}$ & $9.263 \mathrm{~ns}$ & $10.778 \mathrm{~ns}$ \\
\hline \multirow{2}{*}{ Use of clean energy } & Abuja & $0.075 \mathrm{~ns}$ & $4.486 \mathrm{~ns}$ & $3.104 \mathrm{~ns}$ & $13.864 \mathrm{~ns}$ & $7.393 \mathrm{~ns}$ \\
\hline & Enugu & $0.298 \mathrm{~ns}$ & $7.016 \mathrm{~ns}$ & $6.427 \mathrm{~ns}$ & $14.945 *$ & $4.433 \mathrm{~ns}$ \\
\hline \multirow{2}{*}{ Proper waste management } & Abuja & $0.454 \mathrm{~ns}$ & $0.788 \mathrm{~ns}$ & $1.285 \mathrm{~ns}$ & $11.049 \mathrm{~ns}$ & $2.279 \mathrm{~ns}$ \\
\hline & Enugu & $0.935 \mathrm{~ns}$ & 5.103 ns & $4.491 \mathrm{~ns}$ & $5.690 \mathrm{~ns}$ & $7.665 \mathrm{~ns}$ \\
\hline \multirow{2}{*}{ Regulations } & Abuja & $0.098 \mathrm{~ns}$ & $2.038 \mathrm{~ns}$ & $2.402 \mathrm{~ns}$ & $11.884 \mathrm{~ns}$ & $1.066 \mathrm{~ns}$ \\
\hline & Enugu & $0.368 \mathrm{~ns}$ & $3.053 \mathrm{~ns}$ & $4.570 \mathrm{~ns}$ & $8.901 \mathrm{~ns}$ & $2.414 \mathrm{~ns}$ \\
\hline \multirow{2}{*}{ Monitoring of AQ } & Abuja & $0.017 \mathrm{~ns}$ & $4.404 \mathrm{~ns}$ & $4.760 \mathrm{~ns}$ & $9.775 \mathrm{~ns}$ & $3.155 \mathrm{~ns}$ \\
\hline & Enugu & $0.325 \mathrm{~ns}$ & 11.348 * & $4.600 \mathrm{~ns}$ & 13.385 * & $5.264 \mathrm{~ns}$ \\
\hline \multirow{2}{*}{ Public awareness } & Abuja & $0.243 \mathrm{~ns}$ & $1.811 \mathrm{~ns}$ & $5.776 \mathrm{~ns}$ & $12.98 \mathrm{~ns}$ & $3.540 \mathrm{~ns}$ \\
\hline & Enugu & $0.528 \mathrm{~ns}$ & $9.076 \mathrm{~ns}$ & $1.392 \mathrm{~ns}$ & $8.918 \mathrm{~ns}$ & $3.127 \mathrm{~ns}$ \\
\hline \multirow{2}{*}{ Reduce and reuse products } & Abuja & $1.862 \mathrm{~ns}$ & $0.494 \mathrm{~ns}$ & $2.878 \mathrm{~ns}$ & $5.870 \mathrm{~ns}$ & $2.753 \mathrm{~ns}$ \\
\hline & Enugu & $0.888 \mathrm{~ns}$ & $3.896 \mathrm{~ns}$ & $9.302 *$ & $7.678 \mathrm{~ns}$ & $4.824 \mathrm{~ns}$ \\
\hline \multirow{2}{*}{ Avoid bush burning } & Abuja & $0.000 \mathrm{~ns}$ & $1.839 \mathrm{~ns}$ & $2.184 \mathrm{~ns}$ & $6.182 \mathrm{~ns}$ & $5.183 \mathrm{~ns}$ \\
\hline & Enugu & $0.618 \mathrm{~ns}$ & $1.544 \mathrm{~ns}$ & $5.605 \mathrm{~ns}$ & $4.307 \mathrm{~ns}$ & $7.631 \mathrm{~ns}$ \\
\hline \multirow{2}{*}{ Tolls for vehicles } & Abuja & $0.058 \mathrm{~ns}$ & $0.655 \mathrm{~ns}$ & $0.145 \mathrm{~ns}$ & $5.690 \mathrm{~ns}$ & $1.762 \mathrm{~ns}$ \\
\hline & Enugu & $0.052 \mathrm{~ns}$ & $5.218 \mathrm{~ns}$ & $4.074 \mathrm{~ns}$ & $7.213 \mathrm{~ns}$ & $5.203 \mathrm{~ns}$ \\
\hline \multirow{2}{*}{ Parking charge for vehicles } & Abuja & $2.360 \mathrm{~ns}$ & 12.883 * & $1.354 \mathrm{~ns}$ & $3.600 \mathrm{~ns}$ & $5.639 \mathrm{~ns}$ \\
\hline & Enugu & $2.185 \mathrm{~ns}$ & $1.569 \mathrm{~ns}$ & $0.581 \mathrm{~ns}$ & $8.760 \mathrm{~ns}$ & $5.690 \mathrm{~ns}$ \\
\hline \multirow{2}{*}{ Reduce air travel } & Abuja & $4.142 *$ & $5.454 \mathrm{~ns}$ & $1.132 \mathrm{~ns}$ & $4.347 \mathrm{~ns}$ & $8.723 \mathrm{~ns}$ \\
\hline & Enugu & $0.710 \mathrm{~ns}$ & $3.391 \mathrm{~ns}$ & $1.784 \mathrm{~ns}$ & $11.287 \mathrm{~ns}$ & $7.437 \mathrm{~ns}$ \\
\hline \multirow{2}{*}{ Use mass transit } & Abuja & $1.125 \mathrm{~ns}$ & $3.532 \mathrm{~ns}$ & $2.369 \mathrm{~ns}$ & $3.807 \mathrm{~ns}$ & $3.562 \mathrm{~ns}$ \\
\hline & Enugu & $1.696 \mathrm{~ns}$ & $6.984 \mathrm{~ns}$ & $3.119 \mathrm{~ns}$ & $9.053 \mathrm{~ns}$ & 15.114 * \\
\hline \multirow{2}{*}{ Better vehicle maintenance } & Abuja & $0.057 \mathrm{~ns}$ & $6.039 \mathrm{~ns}$ & $3.876 \mathrm{~ns}$ & $9.342 \mathrm{~ns}$ & $8.324 \mathrm{~ns}$ \\
\hline & Enugu & 0.153 ns & $4.984 \mathrm{~ns}$ & $2.354 \mathrm{~ns}$ & $8.542 \mathrm{~ns}$ & $5.742 \mathrm{~ns}$ \\
\hline
\end{tabular}

Figures in the table are the Kruskal-Wallis statistic $p \leq 0.05 ; \mathrm{ns}=$ not significant. Highlighted cells indicate the presence of significant differences within the demographic group by PAQ control measure at $p 0.05$ or greater.

\subsection{Primary Responsibility of Implementing PAQ Control Measures}

Figure 5a,b illustrates the viewpoints of the residents of Abuja and Enugu on who should take the lead in ensuring improved $\mathrm{AQ}$ in both cities. The Spearman rank correlation for the mean scores of organisations having primary responsibility for addressing PAQ from Abuja and Enugu is $0.1(p>0.05)$, suggesting that the respondents from the two cities do take very different views. In Abuja, the people believe that the federal government should be in the primary position to tackle PAQ, and they see NGOs as the least expected 
to implement control measures against PAQ. Conversely, participants in Enugu see the federal government as the least important when it comes to implementing such measures and would rather take the lead themselves as members of the public in conjunction with the state government.

Table 8. Mean scores, standard deviations (SD) and Kruskal-Wallis (KW) test results for age groups and control measures of PAQ for Abuja and Enugu.

\begin{tabular}{|c|c|c|c|c|c|}
\hline \multirow[b]{2}{*}{ Control Measures } & \multirow[b]{2}{*}{ Age Group } & \multicolumn{2}{|c|}{ Abuja } & \multicolumn{2}{|c|}{ Enugu } \\
\hline & & Mean (SD) & KW & Mean (SD) & KW \\
\hline \multirow{2}{*}{ Energy saving } & 18-34 years & $3.16(2.88)$ & \multirow{2}{*}{$2.44 \mathrm{~ns}$} & $2.63(1.24)$ & \multirow{2}{*}{$13.04^{* * *}$} \\
\hline & 35 years and above & $4.04(3.57)$ & & $3.49(1.30)$ & \\
\hline \multirow{2}{*}{ Reduce car use } & 18-34 years & $4.28(3.18)$ & \multirow{2}{*}{$0.91 \mathrm{~ns}$} & $2.95(1.14)$ & \multirow{2}{*}{$8.19 * *$} \\
\hline & 35 years and above & $4.04(3.17)$ & & $3.58(1.07)$ & \\
\hline \multirow{2}{*}{ Reduce motorcycle use } & 18-34 years & $3.44(2.56)$ & \multirow{2}{*}{$0.00 \mathrm{~ns}$} & $2.78(1.17)$ & \multirow{2}{*}{$11.89^{* * *}$} \\
\hline & 35 years and above & $3.68(3.03)$ & & $3.54(1.15)$ & \\
\hline \multirow{2}{*}{ Walking/cycling } & 18-34 years & $3.79(2.82)$ & \multirow{2}{*}{$1.12 \mathrm{~ns}$} & $2.90(1.37)$ & \multirow{2}{*}{$4.54 *$} \\
\hline & 35 years and above & $3.47(2.71)$ & & $3.42(1.40)$ & \\
\hline \multirow{2}{*}{ Use of Energy efficient products } & 18-34 years & $3.43(3.14)$ & \multirow{2}{*}{$2.10 \mathrm{~ns}$} & $2.20(1.27)$ & \multirow{2}{*}{$20.12^{* * *}$} \\
\hline & 35 years and above & $2.71(2.38)$ & & $3.18(1.14)$ & \\
\hline \multirow{2}{*}{ Use of clean energy } & $18-34$ years & $2.75(2.60)$ & \multirow{2}{*}{$0.25 \mathrm{~ns}$} & $1.95(1.13)$ & \multirow{2}{*}{$14.77^{* * *}$} \\
\hline & 35 years and above & $2.72(2.71)$ & & $2.80(1.29)$ & \\
\hline \multirow{2}{*}{ Proper waste management } & 18-34 years & $2.31(2.34)$ & \multirow{2}{*}{$0.20 \mathrm{~ns}$} & $1.72(1.11)$ & \multirow{2}{*}{$14.66^{* * *}$} \\
\hline & 35 years and above & $2.09(2.08)$ & & $2.32(1.09)$ & \\
\hline \multirow{2}{*}{ Regulations } & 18-34 years & $2.56(2.31)$ & \multirow{2}{*}{$0.61 \mathrm{~ns}$} & $2.10(1.18)$ & \multirow{2}{*}{$4.87^{*}$} \\
\hline & 35 years and above & $2.86(2.69)$ & & $2.54(1.21)$ & \\
\hline Monitoring of $\mathrm{AO}$ & 18-34 years & $2.93(2.93)$ & $000 \mathrm{~ns}$ & $1.88(1.17)$ & $1872 * * *$ \\
\hline & 35 years and above & $3.01(2.99)$ & $0.00 \mathrm{~ns}$ & $2.95(1.45)$ & $18 . / 2$ \\
\hline & 18-34 years & $2.69(2.67)$ & & $1.85(1.10)$ & \\
\hline Public awareness & 35 years and above & $2.97(3.00)$ & $0.15 \mathrm{~ns}$ & $2.22(1.07)$ & $6.58^{* x-x}$ \\
\hline Reduce and rouse products & 18-34 years & $3.07(2.93)$ & & $2.18(1.14)$ & \\
\hline Keduce and reuse products & 35 years and above & $3.14(2.64)$ & $1.12 \mathrm{~ns}$ & $2.71(1.31)$ & $5.16^{*}$ \\
\hline Avoid bush burning & 18-34 years & $2.03(1.75)$ & $045 \mathrm{~ns}$ & $1.77(1.05)$ & $707 * *$ \\
\hline & 35 years and above & $2.75(3.03)$ & $0.45 \mathrm{~ns}$ & $2.25(1.15)$ & $7.07+4$ \\
\hline Tolls for vehicles & 18-34 years & $4.15(3.71)$ & & $2.62(1.30)$ & $571 *$ \\
\hline Iolls for vehicles & 35 years and above & $4.32(3.80)$ & $0.08 \mathrm{~ns}$ & $3.15(1.28)$ & $5.71^{*}$ \\
\hline Parking charge for vehicles & 18-34 years & $3.59(3.12)$ & $023 \mathrm{~ns}$ & $3.02(1.28)$ & $087 \mathrm{~ns}$ \\
\hline & 35 years and above & $3.68(3.02)$ & $0.23 \mathrm{~ns}$ & $3.18(1.21)$ & $0.8 / \mathrm{ns}$ \\
\hline & 18-34 years & $4.48(3.39)$ & & $3.32(1.19)$ & \\
\hline Reduce air travel & 35 years and above & $4.41(3.42)$ & $0.06 \mathrm{~ns}$ & $3.71(1.09)$ & $3.54 \mathrm{~ns}$ \\
\hline Use mass transit & 18-34 years & $3.93(3.30)$ & $132 \mathrm{~ns}$ & $3.05(1.19)$ & $757 * *$ \\
\hline Use mass transit & 35 years and above & $3.58(3.21)$ & $1.32 \mathrm{~ns}$ & $3.62(0.96)$ & $7.57^{* * *}$ \\
\hline Better vehicle maintenance & 18-34 years & $2.98(2.91)$ & & $1.95(1.17)$ & $630 *$ \\
\hline detter vente mamtenance & 35 years and above & $2.79(2.69)$ & $1.10 \mathrm{~ns}$ & $2.38(1.16)$ & 0.00 \\
\hline
\end{tabular}

$* p \leq 0.05 ; * * \leq 0.01 ; * * * \leq 0.001 ; \mathrm{ns}=$ not significant. Highlighted cells indicate the presence of significant differences within the demographic group by PAQ control measure at $p 0.05$ or greater. 


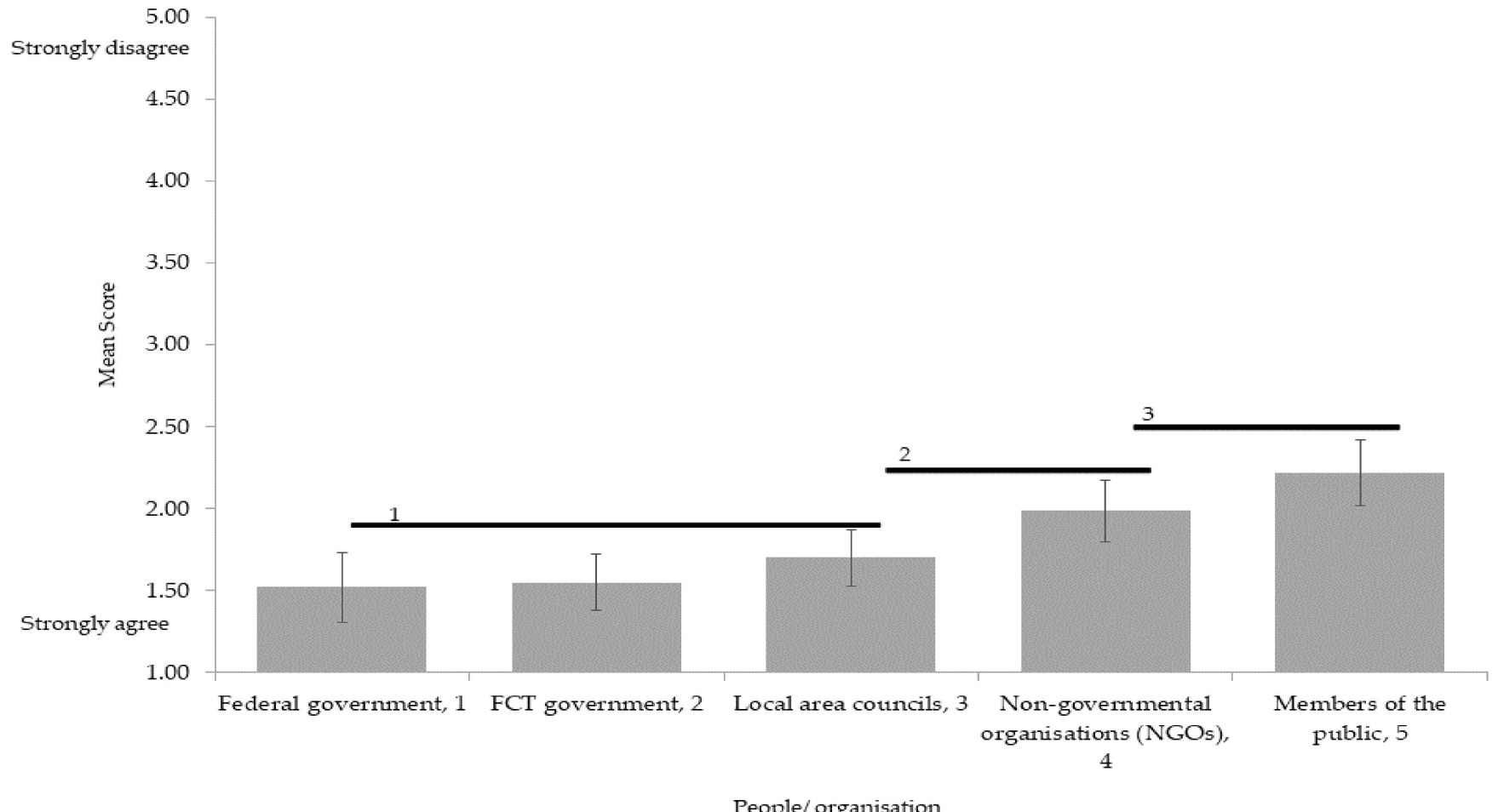

(a)

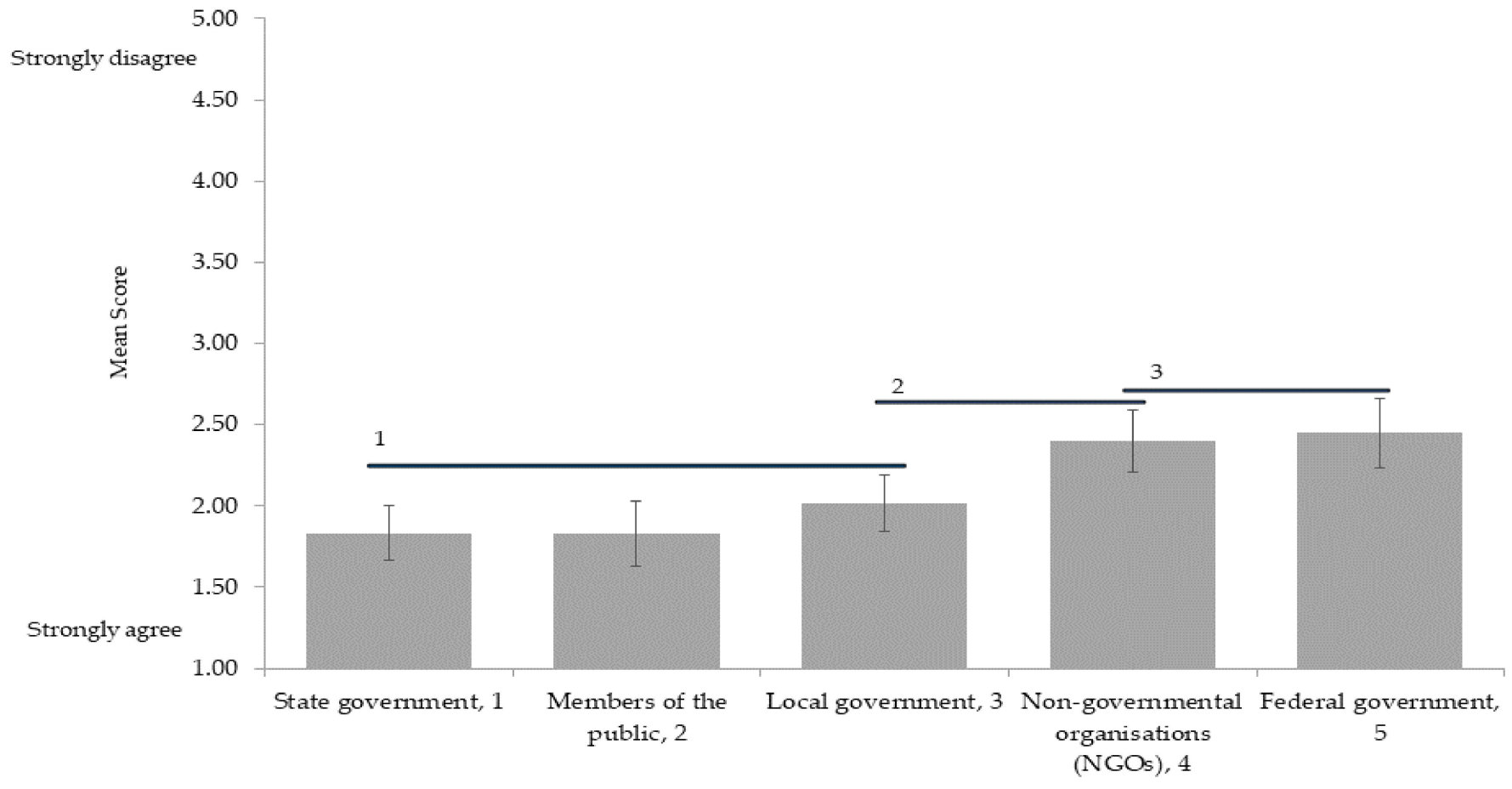

People/ organisation

(b)

Figure 5. (a). Residents' perception of primary responsibility for PAQ control in Abuja. (b). Residents' perception of primary responsibility for PAQ control in Enugu. Numbers on the horizontal axis are the ranks for the perceptual indicators. Error bars are the $95 \%$ confidence interval for the means. Horizonal bars (and numbers) are the groups identified via the Hochberg post hoc test as significant at $p<0.05$. 
Table 9 shows that in most cases (53 out of 60 Kruskal-Wallis tests), there were no significant differences within the demographic groups based on gender, income, education and main mode of transport in how the people or organisations who should take primary responsibility for tackling PAQ were scored. A few statistically significant differences were found among the education and occupation demographic groups in Abuja and the income group in Enugu. For example, those with more advanced educational qualifications in Abuja believed that members of the public should take the principal responsibility for implementing control of PAQ, as indeed did the self-employed and housewives. However, the age demographic in Enugu showed consistent significant differences for four organisations in terms of the principal responsibility in managing PAQ (Table 10). For all four of these organisations-federal government, FCT/state government, local area council/government and non-governmental organisations-the younger demographic (18 to 34 years) saw them as more important than did the older ( $>35$ years) demographic.

Table 9. Results of Kruskal-Wallis tests for a series of demographic groups (other than age) on the scores of agencies responsible for controlling poor air quality (PAQ) in Abuja and Enugu.

\begin{tabular}{ccccccc}
\hline Organization & Cities & Gender & Income & Education & Occupation & Transportation \\
\hline \multirow{2}{*}{ Federal Government } & Abuja & $0.246 \mathrm{~ns}$ & $7.196 \mathrm{~ns}$ & $3.722 \mathrm{~ns}$ & $3.863 \mathrm{~ns}$ & $9.402 \mathrm{~ns}$ \\
\cline { 2 - 7 } & Enugu & $0.252 \mathrm{~ns}$ & $11.970 *$ & $3.666 \mathrm{~ns}$ & $8.915 \mathrm{~ns}$ & $3.183 \mathrm{~ns}$ \\
\hline \multirow{2}{*}{ FCT/State Government } & Abuja & $0.973 \mathrm{~ns}$ & $5.817 \mathrm{~ns}$ & $4.729 \mathrm{~ns}$ & $9.587 \mathrm{~ns}$ & $8.261 \mathrm{~ns}$ \\
\cline { 2 - 7 } & Enugu & $0.392 \mathrm{~ns}$ & $5.895 \mathrm{~ns}$ & $1.166 \mathrm{~ns}$ & $4.647 \mathrm{~ns}$ & $4.221 \mathrm{~ns}$ \\
\hline $\begin{array}{c}\text { Local Area } \\
\text { Council/Government }\end{array}$ & Abuja & $2.112 \mathrm{~ns}$ & $5.378 \mathrm{~ns}$ & $0.702 \mathrm{~ns}$ & $4.949 \mathrm{~ns}$ & $5.164 \mathrm{~ns}$ \\
\cline { 2 - 7 } $\begin{array}{c}\text { Non-governmental } \\
\text { Organizations }\end{array}$ & Enugu & $0.114 \mathrm{~ns}$ & $8.754 \mathrm{~ns}$ & $4.918 \mathrm{~ns}$ & $8.668 \mathrm{~ns}$ & $6.470 \mathrm{~ns}$ \\
\cline { 2 - 7 } & Abuja & $0.000 \mathrm{~ns}$ & $3.842 \mathrm{~ns}$ & $2.947 \mathrm{~ns}$ & $2.730 \mathrm{~ns}$ & $6.532 \mathrm{~ns}$ \\
\hline \multirow{2}{*}{\begin{tabular}{c} 
Members of the Public \\
\cline { 2 - 7 }
\end{tabular}} & Abuja & $0.816 \mathrm{~ns}$ & $4.025 \mathrm{~ns}$ & $9.836 *$ & $15.573 *$ & $3.611 \mathrm{~ns}$ \\
\hline
\end{tabular}

Figures in the table are the Kruskal-Wallis statistic * $p \leq 0.05 ; \mathrm{ns}=$ not significant. Highlighted cells indicate the presence of significant differences within the demographic groups per organisation/people responsible for PAQ control measure at $p 0.05$ or greater.

Table 10. Means, standard deviations (SD) and Kruskal-Wallis test results for the age demographic group and primary responsibility for control of poor air quality (PAQ) in Abuja and Enugu.

\begin{tabular}{|c|c|c|c|c|c|}
\hline \multirow[b]{2}{*}{ Organisation/Agency } & \multirow[b]{2}{*}{ Age Groups } & \multicolumn{2}{|c|}{ Abuja } & \multicolumn{2}{|c|}{ Enugu } \\
\hline & & Mean (SD) & KW & Mean (SD) & KW \\
\hline \multirow{2}{*}{ Federal Government } & 18-34 years & $1.56(0.79)$ & \multirow{2}{*}{$0.37 \mathrm{~ns}$} & $2.02(1.13)$ & \multirow{2}{*}{$14.94^{* * *}$} \\
\hline & 35 years and above & $1.49(0.72)$ & & $2.85(1.16)$ & \\
\hline \multirow{2}{*}{ FCT/State Government } & 18-34 years & $1.62(0.76)$ & \multirow{2}{*}{$0.70 \mathrm{~ns}$} & $1.57(0.93)$ & \multirow{2}{*}{$10.86^{* * *}$} \\
\hline & 35 years and above & $1.49(0.60)$ & & $2.08(0.94)$ & \\
\hline \multirow{2}{*}{$\begin{array}{c}\text { Local Area } \\
\text { Council/Government }\end{array}$} & 18-34 years & $1.67(0.77)$ & \multirow{2}{*}{$0.30 \mathrm{~ns}$} & $1.72(0.90)$ & \multirow[b]{2}{*}{$12.93^{* * *}$} \\
\hline & 35 years and above & $1.74(0.82)$ & & $2.31(0.97)$ & \\
\hline \multirow{2}{*}{$\begin{array}{c}\text { Non-governmental } \\
\text { Organizations }\end{array}$} & $18-34$ years & $2.20(1.09)$ & \multirow{2}{*}{$0.12 \mathrm{~ns}$} & $1.98(0.98)$ & \multirow{2}{*}{$19.47^{* * *}$} \\
\hline & 35 years and above & $2.24(1.02)$ & & $2.78(0.99)$ & \\
\hline \multirow{2}{*}{ Members of the Public } & 18-34 years & $2.02(1.20)$ & \multirow{2}{*}{$0.08 \mathrm{~ns}$} & $1.68(0.97)$ & \multirow{2}{*}{$1.11 \mathrm{~ns}$} \\
\hline & 35 years and above & $1.96(1.16)$ & & $1.97(1.25)$ & \\
\hline
\end{tabular}

${ }^{* *} p \leq 0.01 ;{ }^{* * *} p \leq 0.001 ; \mathrm{ns}=$ not significant. Highlighted cells indicate the presence of significant differences within the age groups per organisation/people responsible for PAQ control measure at $p 0.05$ or greater. 


\section{Discussion}

This research represents the first work on the views of people from the cities of Abuja and Enugu in Nigeria regarding their perceived indicators of PAQ, causes of PAQ, and what should be done about it and by whom. Seeking the views of those who are most affected by PAQ is a logical move, although to date the emphasis has tended to be on the use of hardware such as monitoring stations and models to assess changes in air quality. When seeking the views of people on their perception of PAQ, its causes and potential solutions, however, it is likely that there will be diversity. Hence, in the research reported here, the emphasis was on exploring potential (i) differences in the perspectives of respondents between the two cities and (ii) for differences between several demographic groups (gender, age, education, income, occupation and main modes of transport). The two cities (Abuja and Enugu) were chosen as their geographical, social and historical contexts are quite different. Abuja is the federal capital of the country, established in the 1970s, and was planned in the sense of having distinct zones as well as wide and parallel roads. Enugu is a much older city and is a state capital, although it briefly was the de facto capital of the short-lived Biafran republic during the Nigerian civil war of the late 1960s.

The results obtained demonstrate that respondents in both cities clearly recognise that they experience PAQ. Indeed, their views over perceptual indicators, causes and controls were broadly similar with little evidence of a clear pattern of significant differences between the demographic groups. The indicators that respondents from the two cities said they used the most were smoke and dust, and odour, and there is some overlap here with the findings of previously published research. For example, studies such as $[49,84-86]$ noted that odour was identified as the main perceived indicator of PAQ. However, it is interesting to note that visibility and factors such as skin and eye irritation and coughing did not score so high as the presence of odour, smoke and dust, and this does contrast to some extent with the results of previous studies. For example, studies by $[8,47,87,88]$ highlighted visual experience or visibility as a widely used indicator, and coughing and sneezing are also used by people who are especially sensitive to PAQ such as those suffering from asthma [88]. Others such as [89-91] have reported that skin and eye irritation are often mentioned as indicators of PAQ. There may be some reasons for this difference in findings compared to the study reported here. For example, in the present research, no attempt was made to stratify the sample based on health conditions, thus, it is possible that many of the respondents were not unduly affected in health terms by PAQ.

When it comes to the perceived main causes of PAQ there was also a high degree of agreement between the two cities and indeed between demographic groups. While some significant differences were noted between some of the demographic groups these were relatively few and there was no clear and consistent pattern of difference. Respondents perceived that combustion-based human activities are the main sources of PAQ, and these include vehicular movement, manufacturing, the use of generators, bush fire (although these tend to happen more in the dry season and at the start of the growing season) and waste incineration. These findings are broadly in line with the results of other published studies. For example, incineration and vehicles as the main sources of PAQ in New Zealand [92], and vehicular emissions and bush burning are perceived by residents as major sources of PAQ in Mathare, a slum in Nairobi, Kenya [49], and the major contribution of vehicles to PAQ was also identified by [93], Ref. [53] in Nanchang, China, and [50] in Columbian cities. These perceptual findings are related to the measuring equipment findings of $[94,95]$ which found that vehicle emissions were the chief cause of air pollution in Enugu city, while the works of [96-98] identified pollution from trucks as one of the top two main sources of PAQ.

The respondents from both cities also broadly agreed about the main control measures of PAQ that should be put in place. Proper waste disposal and incineration, and the avoidance of bush burning were scored highly by respondents, and this agrees with the findings of [53] who noted that control and reduction of waste burning is one of the most important means of solving PAQ problems in China. At the other end of the scale, 
respondents were not so positive about methods for controlling vehicle use or indeed the use of walking, cycling and mass transit systems such as train, and this is somewhat at odds with recommendations that are often espoused by international agencies such as the World Health Organization [99]. Reducing air travel was seen as the least effective of all measures for controlling PAQ in both cities. Allied to this point about control measures was the question asked in the survey about who be the agency that is primarily responsible for implementation of the measures. Here, there were some divergences between the responses of Abuja and Enugu respondents, with the former emphasising the role of the federal government while the latter focused more on the role of the state government. Indeed, Enugu respondents regarded the federal government as the least relevant when it comes to implementing PAQ control measures. In part, this may be due to the points made earlier in the paper about people generally having greater trust in more local agencies compared to national ones $[57,58]$, but there could be other and more intriguing factors at play, clues to which can be found in the results of the demographic-based analyses.

Generally, and in line with points made above for indicators and causes of PAQ, there were very few statistically significant differences in how the various demographic groups perceived PAQ control measures and who are the main agencies for implementation in this study. There were some statistical differences for gender, income, education, occupation and main means of transport, but these were few in number and with no clear pattern. However, a striking exception to this was in Enugu, where a pattern of statistically significant differences within the age demographic occurred for many of the control measures and for who should be the main agents for their implementation. The results suggest that the younger demographic, those classified as 'youth', 18-34 years old, by the Nigerian Government, scored the control measures consistently higher than did the older (>35 years old) demographic (Table 7) and were also more positive about the role of most agencies for implementing the measures (Table 10). This significant and striking difference between age groups in the Enugu sample was not seen in Abuja, and indeed did not appear in the results of the Kruskal-Wallis tests for perceived indicators and main causes of PAQ. It must first be noted that the questions in the survey which looked at control measures and agency are intrinsically different from those questions that ask about indicators and causes of PAQ as the former questions have an inherent sense of responsibility, governance and power within them - they are about 'someone doing something' rather than the arguably more neutral questions about indicators and causes of PAQ. Indeed, and following on from this point, one interesting possibility is linked to the more multi-ethnic and multi-cultural nature of the Abuja sample which has respondents from Tiv, Yoruba, Igbo, Hausa, Fulani, Edo, Idoma, Igala, Efik, Ibibio, Gbagyi, Ijaw, Eggon, and Berom.

Indeed, the geographical location of the city in the centre of Nigeria was designed in part to enhance that diversity, compared to Enugu which is still largely an Igbo city or at least a city primarily inhabited by peoples from the South-East of the country. There are some intriguing dynamics at play in Igbo culture, including some that are deeply rooted in Igbo youth identity and activism and in particular the sense of difference between youth and their elders when it comes to power and decision-making, all of which are said to be finding new voices in more recent years especially while linked to the latest re-emergence of a desire to separate from the Nigerian state [100,101]. The Igbos are highly democratic and always inculcate democratic values [102] in everything which most times commence from the traditional 'age grades'; a group that usually mark the onset of youthful years. In many societies within Nigeria, power rests with the elders rather than the youth, and there has always been some tension here, with a growing literature pointing to restiveness and calls from the youth to be more involved in decision-making [103] and indeed politics [104]. However, in the south-east of the country, there has arguably been an especial rise in youth-led environmental activism as a result of degradation caused by the extractive (i.e., oil and gas) industry and Igbo society in particular has been seeing the emergence of youth activism, including with environmental matters, and the youth have been finding their voices especially within urban contexts. Maybe the significant differences between the age 
groups in Enugu are linked to a sense of urgency and importance to address PAQ amongst the youth when compared to the older segment in the sample is in part a reflection of this confidence and voice. This is an intriguing possibility that would need to be followed up with further research.

A point that needs to be noted in the context of this study is the potential influence of the COVID-19 pandemic lockdown on respondents' views of urban air quality. After all, the research took place during a peak of the COVID-19 pandemic (October 2020 and March 2021) and many of the respondents identified vehicular movement and other anthropogenic activities as the main causes of PAQ in their urban environment. On a global scale, air travel and shipping were affected and, in many countries, road transport was significantly reduced. As a result of these and other changes, such as a reduction in industrial activity, there are many reports that the concentration of pollutants in the atmosphere reduced during the lockdown period [105-109]. However, while there is no evidence as yet that vehicle movement was significantly reduced in Nigerian cities at the time of the research [110], it is not inconceivable that respondents' perception of the causes of air quality and the best ways to address them could have been influenced via press reporting and social media.

Decision-making on the environment and urban development should be a participatory process, employing public perceptions of the environment including air quality, and giving members of the public the chance to convey their views and concerns. Ensuring a smart and clean city will undoubtedly profit from incorporating study of the perceptions of residents as a means to better understand their views about their locale and reducing environmental risks. This approach to assessing PAQ and its management offers considerable scope for further development in both study areas and beyond, and should be explored further in relation to meeting the SDGs targets and creating a better environment.

\section{Conclusions}

This study has investigated the views of respondents across a wide range of demographic groups to the indicators, sources and responses to PAQ in two structurally different cities in Nigeria. The findings have shed important light onto the potential value of such perceptual indicators to reveal the ways in which citizens recognise the problem of PAQ and how they perceive possible responses to and responsibilities for action on the issue. The following specific conclusions have been drawn from our analysis:

- $\quad$ Respondents in both Abuja and Enugu have clear and very similar perceptions that they are exposed to PAQ.

- $\quad$ Odour, dust and smoke are the most frequently used perceptual indicators of PAQ in the Nigerian cities of Abuja and Enugu. This mirrors similar findings in studies in other parts of the world.

- Combustion-based human activities such as vehicular movement, manufacturing, the use of generators, bush fires and waste-related activities are the main perceived sources of PAQ in both cities. These were also reflected in the views expressed in both cities on the main control measures being proper waste disposal and incineration and the avoidance of bush burning. Respondents were less positive about methods for controlling vehicle use or indeed the use of walking, cycling and mass transit systems. Statistically significant differences in views within the age demographic for the majority of the control measures were observed in Enugu but not Abuja.

- Views on the preferred agencies for implementing control measured diverged between Abuja and Enugu, with residents in the former favouring the federal government and those in the latter favouring local government. An interesting focus for this divergence that applied to both the control measures and the agencies occurred in the age demographic in Enugu where the 'youth' (18-34 years) scored the control measures significantly more highly and were significantly more positive about the responsibilities for implementing the controls than the older demographic ( $>35$ years). 
This finding may reflect youth activism in Enugu and warrants further research in relation to the PAQ issue.

This work suggests that enhanced study and knowledge of people's perceptions of $P A Q$, its causes, interventions to address it and main agencies responsible for controlling PAQ are important areas for future research and will be vital in decision and policymaking to ensure improved air quality in urban areas. There is scope to introduce a more participatory approach to addressing these points and indeed further exploration of the role of youth activism in cities of the global south when it comes to environmental issues.

Author Contributions: Conceptualization, T.M.C., S.M., R.M.; methodology, T.M.C., S.M., R.M.; formal analysis, T.M.C., S.M., R.M.; investigation, T.M.C.; resources, T.M.C., S.M., R.M.; data curation, T.M.C.; writing—original draft preparation, T.M.C.; writing—review and editing, T.M.C., S.M., R.M.; supervision, S.M., R.M.; project administration, S.M.; funding acquisition, T.M.C., S.M., R.M. All authors have read and agreed to the published version of the manuscript.

Funding: The authors are grateful for financial and related support provided to the $\mathrm{PhD}$ programme of the first author by the Faculty of Engineering \& Physical Sciences and the University of Surrey.

Institutional Review Board Statement: Not applicable.

Informed Consent Statement: Not applicable.

Data Availability Statement: Data presented in this study are available on request from the corresponding author.

Acknowledgments: The authors are grateful to our assistants for their help with data collection.

Conflicts of Interest: The authors declare no conflict of interest.

\section{Appendix A \\ Survey Questionnaire \\ SECTION A: DEMOGRAPHICS \\ What is your gender?}

\begin{tabular}{ll}
\hline Male & Female \\
\hline What is your age? & \\
\hline $18-34$ & 35 or older \\
\hline
\end{tabular}

Which one of the following categories best describes your monthly income in Naira?

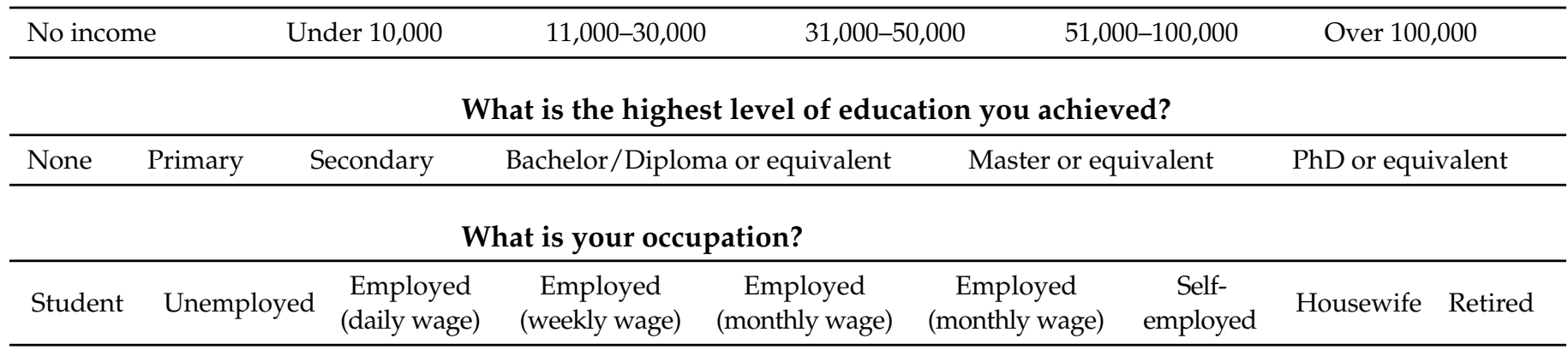

What is your main mode of daily transport?

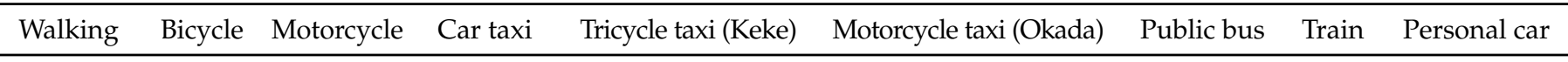


SECTION B: AIR QUALITY PERCEPTUAL INDICATORS

How do you use these indicators to know when the air quality is poor or good?

\begin{tabular}{|c|c|c|c|c|c|}
\hline & Most Used & Used & Neutral & Rarely Used & Least Used \\
\hline \multicolumn{6}{|l|}{ Visibility. } \\
\hline \multicolumn{6}{|l|}{ Smell/odour. } \\
\hline \multicolumn{6}{|l|}{ Dust in the air. } \\
\hline \multicolumn{6}{|l|}{ Dirt on skin and clothes. } \\
\hline \multicolumn{6}{|c|}{ Dirt on surfaces such as buildings. } \\
\hline \multicolumn{6}{|l|}{ Smoke. } \\
\hline \multicolumn{6}{|l|}{ Sneezing and coughing. } \\
\hline \multicolumn{6}{|l|}{ Skin irritation. } \\
\hline Watery/irritating eyes. & & & & & \\
\hline
\end{tabular}

SECTION C: SOURCES OF POOR AIR QUALITY

In general, do you agree that these sources of air pollution contribute to poor air quality?

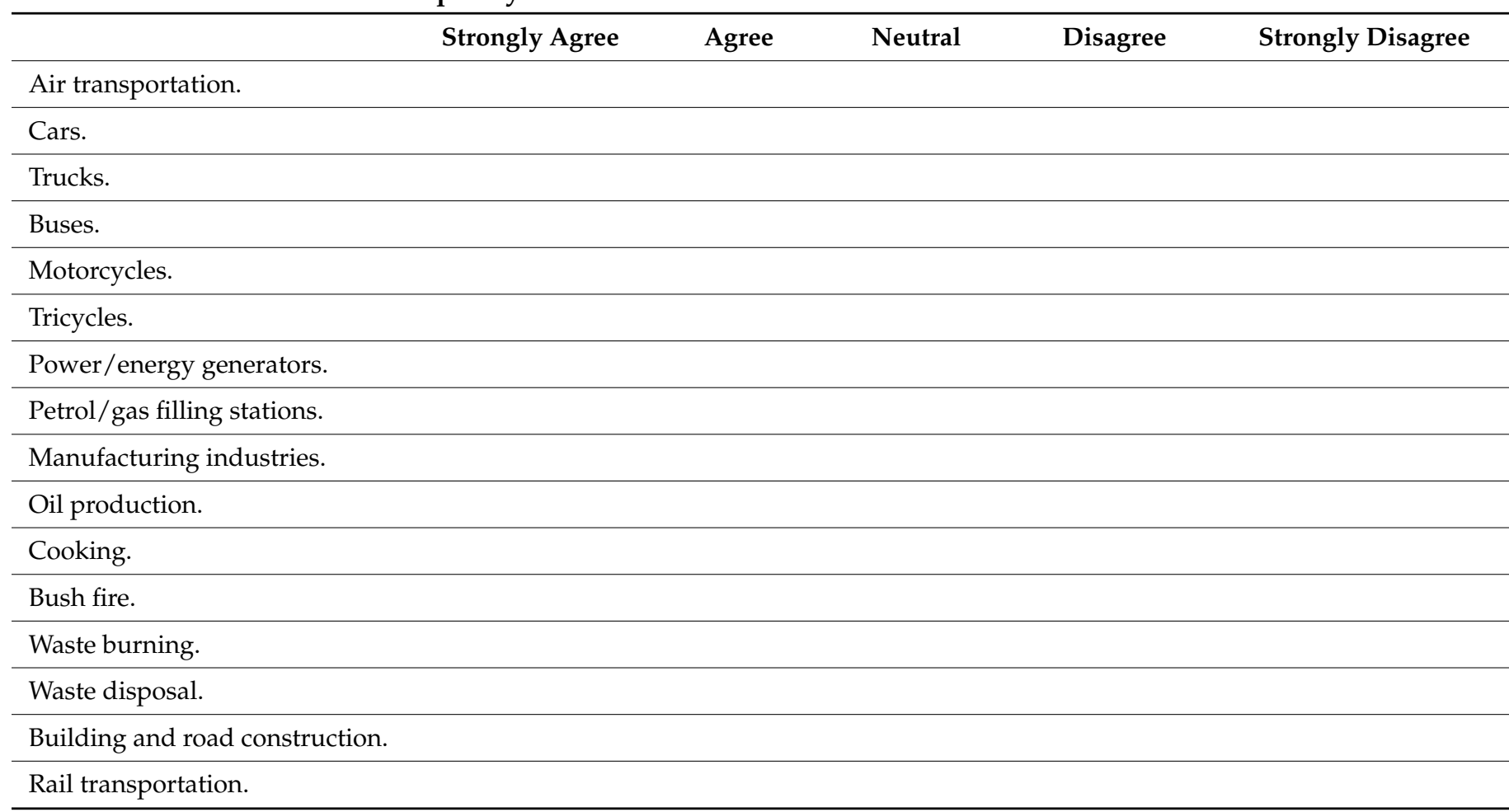


SECTION D: AIR QUALITY CONTROL MEASURES

How do you rate these poor air quality control measures in terms of effectiveness?

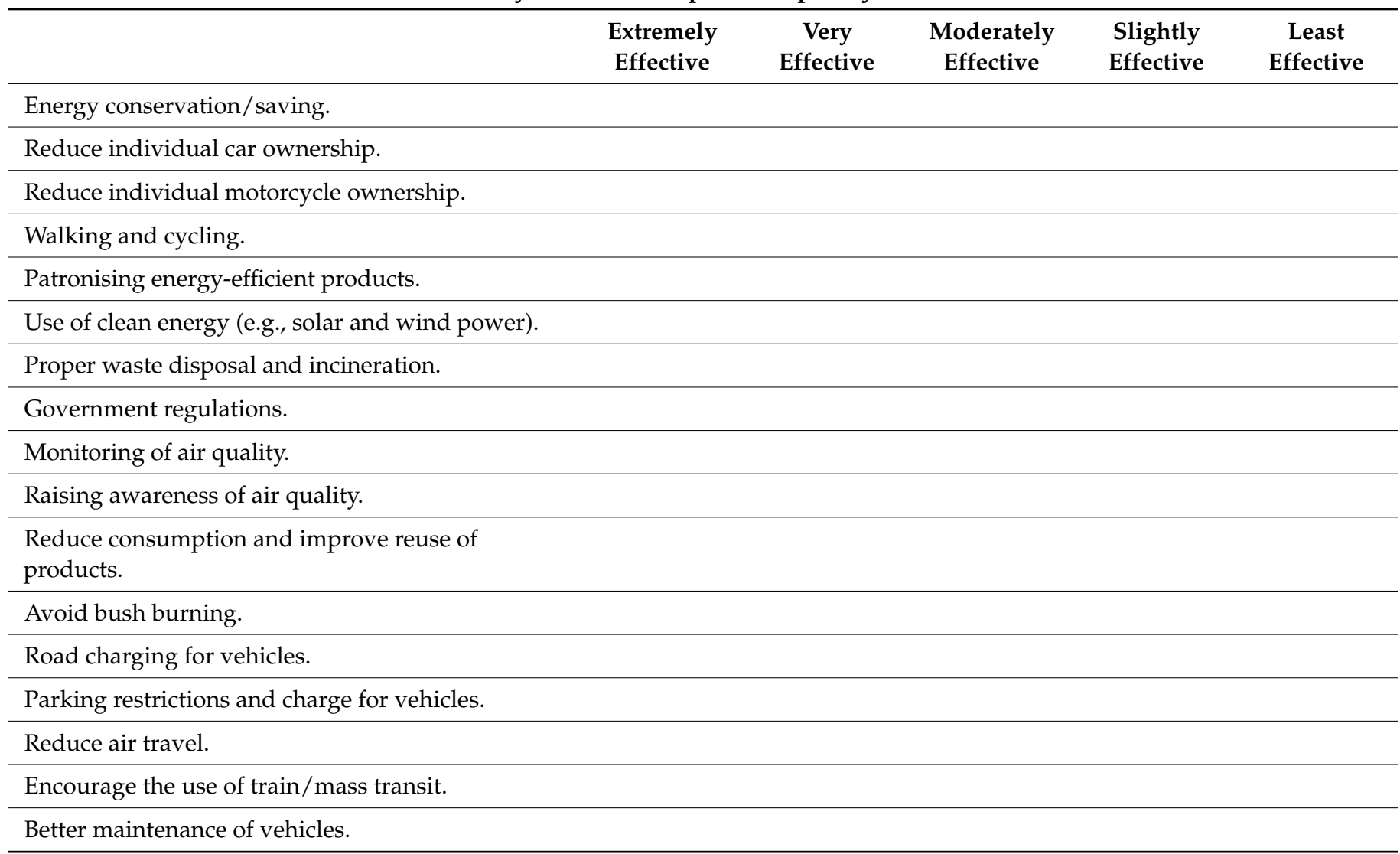

Who should take primary responsibility for improving air quality?

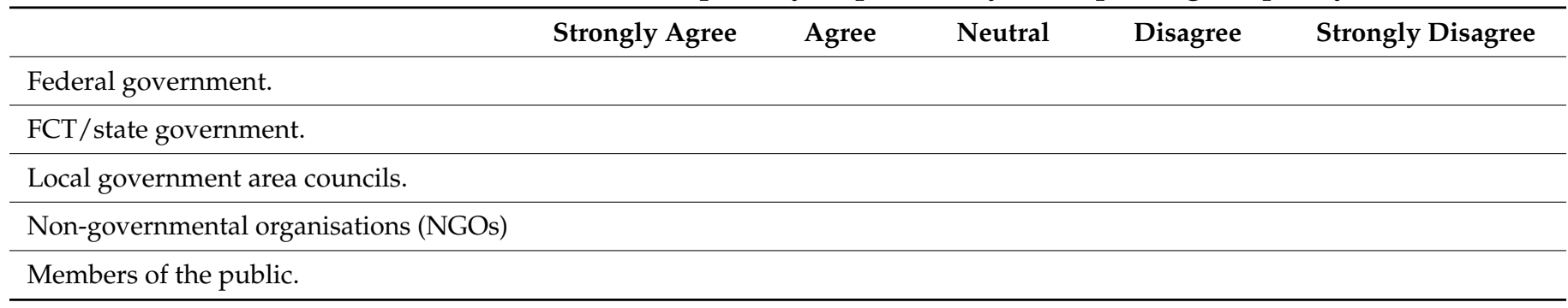

\section{References}

1. Xie, X.; Semanjski, I.; Gautama, S.; Tsiligianni, E.; Deligiannis, N.; Rajan, R.; Philips, W. A Review of Urban Air Pollution Monitoring and Exposure Assessment Methods. ISPRS Int. J. Geo Inf. 2017, 6, 389. [CrossRef]

2. Avtar, R.; Saurabh, T.; Aggarwal, A.K.; Kumar, P. Population-Urbanization-Energy Nexus: A Review. Resources 2019, 8, 136. [CrossRef]

3. Odonkor, S.T.; Mahami, T. Knowledge, Attitudes, and Perceptions of Air Pollution in Accra, Ghana: A Critical Survey. J. Environ. Public. Health 2020, 2020, 3657161. [CrossRef]

4. Mafizur, R.M.; Vu, X.B. Are Energy Consumption, Population Density and Exports Causing Environmental Damage in China? Autoregressive Distributed Lag and Vector Error Correction Model Approaches. Sustainability 2021, 13, 3749. [CrossRef]

5. Agbo, K.E.; Walgraeve, C.; Eze, J.I.; Ugwoke, P.E.; Ukoha, P.O.; Van Langenhove, H. A review on ambient and indoor air pollution status in Africa. Atmos. Pollut. Res. 2021, 12, 243-260. [CrossRef]

6. World Health Organization. New WHO Global Air Quality Guidelines Aim to Save Millions of Lives from Air Pollution. 2021. Available online: https:/ / www.who.int/news/item/22-09-2021-new-who-global-air-quality-guidelines-aim-to-save-millionsof-lives-from-air-pollution (accessed on 20 October 2021).

7. World Health Organization. WHO Global Air Quality Guidelines. Particulate Matter (PM 2.5 and PM 10), Ozone, Nitrogen Dioxide, Sulphur Dioxide and Carbon Monoxide. 2021. Available online: https://www.who.int/publications/i/item/97892400 34433 (accessed on 20 October 2021). 
8. Brimblecombe, P. Visibility Driven Perception and Regulation of Air Pollution in Hong Kong, 1968-2020. Environments 2021, 8, 51. [CrossRef]

9. Perera, F.P. Multiple Threats to Child Health from Fossil Fuel Combustion: Impacts of Air Pollution and Climate Change. Environ. Health Perspect. 2017, 125, 141-148. [CrossRef]

10. Eguiluz-Gracia, I.; Mathioudakis, A.G.; Bartel, S.; Vijverberg, S.J.H.; Fuertes, E.; Comberiati, P.; Cai, Y.S.; Tomazic, P.V.; Diamant, Z.; Vestbo, J.; et al. The need for clean air: The way air pollution and climate change affect allergic rhinitis and asthma. Allergy 2020, 75, 2170-2184. [CrossRef]

11. Scotland's Environment. Air Quality. 2011. Available online: https://www.environment.gov.scot/media/1241/air-and-climateair-quality.pdf (accessed on 22 October 2021).

12. Rao, N.V.; Rajasekhar, M.; Rao, G.C. Detrimental Effect of Air Pollution, Corrosion on Building Materials and Historical Structures. Am. J. Eng. Res. 2014, 3, 359-364.

13. Strosnider, H.; Kennedy, C.; Monti, M.; Yip, F. Rural and Urban Differences in Air Quality, 2008-2012, and Community Drinking Water Quality, 2010-2015-United States. Morbidity and mortality weekly report. Surveill. Summ. 2017, 66, 1-10. [CrossRef] [PubMed]

14. Grimmond, C.S.B.; Roth, M.; Oke, T.R.; Au, Y.C.; Best, M.; Betts, R.; Carmichael, G.; Cleugh, H.; Dabberdt, W.; Emmanuel, R.; et al. Climate and more sustainable cities: Climate information for improved planning and management of cities (Producers/Capabilities Perspective). Procedia Environ. Sci. 2010, 1, 247-274. [CrossRef]

15. Manisalidis, I.; Stavropoulou, E.; Stavropoulos, A.; Bezirtzoglou, E. Environmental and Health Impacts of Air Pollution: A Review. Front. Public Health 2020, 8, 14. [CrossRef] [PubMed]

16. Quarmby, S.; Santos, G.; Mathias, M. Air quality strategies and technologies: A rapid review of the international evidence. Sustainability 2019, 11, 2757. [CrossRef]

17. Amann, M.; Kiesewetter, G.; Schpp, W.; Klimont, Z.; Winiwarter, W.; Cofala, J.; Rafaj, P.; Hglund-Isaksson, L.; Gomez-Sabriana, A.; Heyes, C.; et al. Reducing global air pollution: The scope for further policy interventions. Philos. Trans. R. Soc. A 2020, 378, 20190331. [CrossRef]

18. Unece.org. Clean Air for Life I UNECE. 2016. Available online: http://unece.org/environment-policy/publications/clean-airlife (accessed on 23 October 2021).

19. Borrego, C.; Costa, A.M.; Ginja, J.; Amorim, M.; Coutinho, M.; Karatzas, K.; Penza, M. Assessment of air quality microsensors versus reference methods: The EuNetAir joint exercise. Atmos. Environ. 2016, 147, 246-263. [CrossRef]

20. Schwela, D. Review of Urban Air Quality in Sub-Saharan Africa Region. 2012. Available online: https://openknowledge. worldbank.org/handle/10986/26864 (accessed on 23 October 2021).

21. Zhang, J.; Day, D. Urban Air Pollution and Health in Developing Countries. In Air Pollution and Health Effects. Molecular and Integrative Toxicology; Nadadur, S., Hollingsworth, J., Eds.; Springer: London, UK, 2015. [CrossRef]

22. Karimi, H.; Soffianian, A.; Mirghaffari, N.; Soltani, S. Determining Air Pollution Potential Using Geographic Information Systems and Multi-criteria Evaluation: A Case Study in Isfahan Province in Iran. Environ. Process. 2016, 3, 229-246. [CrossRef]

23. Zhou, C.; Li, S.; Wang, S. Examining the impacts of urban form on air pollution in developing countries: A case study of China's megacities. Int. J. Environ. Res. Public Health 2018, 15, 1565. [CrossRef]

24. Kumar, P.; Druckman, A.; Gallagher, J.; Gatersleben, B.; Allison, S.; Eisenman, T.S.; Hoang, U.; Hama, S.; Tiwari, A.; Sharma, A.; et al. The nexus between air pollution, green infrastructure and human health. Environ. Int. 2019, 133, 105181. [CrossRef]

25. Abulude, F.O.; Damodharan, U.; Acha, S.; Adamu, A.; Arifalo, K.M. Preliminary Assessment of Air Pollution Quality Levels of Lagos, Nigeria. Environ. Sci. Proc. 2020, 5, 20. [CrossRef]

26. De Souza, P.; Anjomshoaa, A.; Duarte, F.; Kahn, R.; Kumar, P.; Ratti, C. Air quality monitoring using mobile low-cost sensors mounted on trash-trucks: Methods development and lessons learned. Sustain. Cities Soc. 2020, 60, 102239. [CrossRef]

27. Mahajan, S.; Kumar, P.; Pinto, J.A.; Riccetti, A.; Schaaf, K.; Camprodon, G.; Smári, V.; Passani, A.; Forino, G. A citizen science approach for enhancing public understanding of air pollution. Sustain. Cities Soc. 2020, 52, 101800. [CrossRef]

28. Abera, A.; Friberg, J.; Isaxon, C.; Jerrett, M.; Malmqvist, E.; Sjöström, C.; Taj, T.; Vargas, A.M. Air Quality in Africa: Public Health Implications. Annu. Rev. Public Health 2021, 42, 193-210. [CrossRef]

29. Singh, A.; Ng'ang'a, D.; Gatari, M.J.; Kidane, A.W.; Alemu, Z.A.; Derrick, N.; Webster, M.J.; Bartington, S.E.; Thomas, G.N.; Avis, W.; et al. Air quality assessment in three East African cities using calibrated low-cost sensors with a focus on road-based hotspots. Environ. Res. Commun. 2021, 3, 075007. [CrossRef]

30. Squizzato, R.; Nogueira, T.; Martins, L.D.; Martins, J.A.; Astolfo, R.; Machado, C.B.; Andrade, M.F.; Freitas, E.D. Beyond megacities: Tracking air pollution from urban areas and biomass burning in Brazil. NPJ Clim. Atmos. Sci. 2021, 4, 17. [CrossRef]

31. Rohde, R.A.; Muller, R.A. Air pollution in China: Mapping of concentrations and sources. PLoS ONE 2015, 10, e0135749. [CrossRef]

32. Akram, M.; Amrani, M.; El, C. Air2Day: An Air Quality Monitoring Adviser in Morocco. Int. J. Comput. Appl. 2018, 181, 1-6. [CrossRef]

33. Semlali, B.E.B.; Amrani, C.; Ortiz, G.; Boubeta-Puig, J.; Garcia-de-Prado, A. SAT-CEP-monitor: An air quality monitoring software architecture combining complex event processing with satellite remote sensing. Comput. Electr. Eng. 2021, 93, 107257. [CrossRef]

34. Castell, N.; Dauge, F.R.; Schneider, P.; Vogt, M.; Lerner, U.; Fishbain, B.; Broday, D.; Bartonova, A. Can commercial low-cost sensor platforms contribute to air quality monitoring and exposure estimates? Environ. Int. 2017, 99, 293-302. [CrossRef] 
35. Greater London Authority. Guide for Monitoring Air Quality in London. 2018. Available online: https://www.london.gov.uk/ sites/default/files/air_quality_monitoring_guidance_january_2018.pdf (accessed on 23 October 2021).

36. Hertel, O. Integrated Monitoring and Assessment of Air Pollution. 2009. Available online: https://www.researchgate.net/ publication/233379382 (accessed on 24 October 2021).

37. Lewis, A.; Edwards, P. Validate personal air-pollution sensors. Nature 2016, 535, 29-31. [CrossRef]

38. Lassman, W.; Pierce, J.R.; Bangs, E.J.; Sullivan, A.P.; Ford, B.; Tsidu, G.M.; Sherman, J.P.; Collett, J.L.; Bililign, S. Using low-cost measurement systems to investigate air quality: A case study in Palapye, Botswana. Atmosphere 2020, 11, 583. [CrossRef]

39. Ikram, J.; Tahir, A.; Kazmi, H.; Khan, Z.; Javed, R.; Masood, U. View: Implementing low cos air quality monitoring solution for urban areas. Environ. Syst. Res. 2012, 1, 10. [CrossRef]

40. Snyder, E.G.; Watkins, T.H.; Solomon, P.A.; Thoma, E.D.; Williams, R.W.; Hagler, G.S.W.; Shelow, D.; Hindin, D.A.; Kilaru, V.J.; Preuss, P.W. The Changing Paradigm of Air Pollution Monitoring. Environ. Sci. Technol. 2013, 47, 11369-11377. [CrossRef] [PubMed]

41. Pinder, R.W.; Klopp, J.M.; Kleiman, G.; Hagler, G.S.W.; Awe, Y.; Terry, S. Opportunities and Challenges for Filling the Air Quality Data Gap in Low- and Middle-Income Countries. Atmos. Environ. 2019, 215, 116794. [CrossRef]

42. Schmitz, S.; Weiand, L.; Becker, S.; Niehoff, N.; Schwartzbach, F.; von Schneidemesser, E. An assessment of perceptions of air quality surrounding the implementation of a traffic-reduction measure in a local urban environment. Sustain. Cities Soc. 2018, 41, 525-537. [CrossRef]

43. Cori, L.; Donzelli, G.; Gorini, F.; Bianchi, F.; Curzio, O. Risk perception of air pollution: A systematic review focused on particulate matter exposure. Int. J. Environ. Res. Public Health 2020, 17, 6424. [CrossRef] [PubMed]

44. Wang, Y.; Sun, M.; Yang, X.; Yuan, X. Public awareness and willingness to pay for tackling smog pollution in China: A case study. J. Clean. Prod. 2016, 112, 1627-1634. [CrossRef]

45. Kondo, M.C.; Mizes, C.; Lee, J.; McGady-Saier, J.; O’Malley, L.; Diliberto, A.; Burstyn, I. Towards Participatory Air Pollution Exposure Assessment in a Goods Movement Community. Prog. Community Health Partnersh. Res. Educ. Action 2014, 8, 291-304. [CrossRef]

46. Laws, M.B.; Yeh, Y.; Reisner, E.; Stone, K.; Wang, T.; Brugge, D. Gender, Ethnicity and Environmental Risk Perception Revisited: The Importance of Residential Location. J. Community Health 2015, 40, 948-955. [CrossRef]

47. Malm, W.C.; Schichtel, B.; Molenar, J.; Prenni, A.; Peters, M. Which visibility indicators best represent a population's preference for a level of visual air quality? J. Air Waste Manag. Assoc. 2018, 69, 145-161. [CrossRef]

48. Ryu, Y.-H.; Min, S.-K. What matters in public perception and awareness of air quality? Quantitative assessment using internet search volume data. Environ. Res. Lett. 2020, 15, 0940b4. [CrossRef]

49. Ngo, N.; Kokoyo, S.; Klopp, J. Why participation matters for air quality studies: Risk perceptions, understandings of air pollution and mobilization in a poor neighborhood in Nairobi, Kenya. Public Health 2017, 142, 177-185. [CrossRef] [PubMed]

50. Ramírez, O.; Mura, I.; Franco, J.F. How Do People Understand Urban Air Pollution? Exploring Citizens' Perception on Air Quality, Its Causes and Impacts in Colombian Cities. Open J. Air Pollut. 2017, 6, 1-17. [CrossRef]

51. Dandotiya, B. Air Pollution, Health and Perception. 2021. Available online: https://www.intechopen.com/chapters/75552 (accessed on 30 October 2021).

52. Peng, M.; Zhang, H.; Evans, R.; Zhong, X.; Yang, K. Actual Air Pollution, Environmental Transparency, and the Perception of Air Pollution in China. J. Environ. Dev. 2019, 28, 78-105. [CrossRef]

53. Liao, X.; Tu, H.; Maddock, J.E.; Fan, S.; Lan, G.; Wu, Y.; Lu, Y. Residents' perception of air quality, pollution sources, and air pollution control in Nanchang, China. Atmos. Pollut. Res. 2015, 6, 835-841. [CrossRef]

54. Maione, M.; Mocca, E.; Eisfeld, K.; Kazepov, Y.; Fuzzi, S. Public perception of air pollution sources across Europe. Ambio 2020, 50, 1150-1158. [CrossRef]

55. Luo, L.; Wu, Y.; Hsu, K.-W.; Ting, P.-H. Public Risk Perception and Response to Air Pollution. IOP Conf. Ser. Earth Environ. Sci. 2020, 581, 012029. [CrossRef]

56. Nigeria, Climate and Clean Air Coalition \& United Nations Environment Programme. Highlights of the National Action Plan to Reduce Short-lived Climate Pollutants in Nigeria/Climate \& Clean Air Coalition. 2018. Available online: https:/ / www.ccacoalition. org/en/resources/highlights-national-action-plan-reduce-short-lived-climate-pollutants-nigeria (accessed on 3 November 2021).

57. Christensen, T.; Lægreid, P. Trust in Government: The relative importance of service satisfaction, political factors, and demography. Public Perform. Manag. Rev. 2005, 28, 487-511.

58. Fitzgerald, J.; Wolak, J. The roots of trust in local government in Western Europe. Int. Political Sci. Rev. 2016, 37, 130-146. [CrossRef]

59. Wu, C.; Wilkes, R. Local-national political trust patterns: Why China is an exception. Int. Political Sci. Rev. 2018, 39, 436-454. [CrossRef]

60. Enoguanbhor, E.C.; Gollnow, F.; Nielsen, J.O.; Lakes, T.; Walker, B.B. Land cover change in the Abuja City-Region, Nigeria: Integrating GIS and remotely sensed data to support land use planning. Sustainability 2019, 11, 1313. [CrossRef]

61. United Nations Population Fund. World Population Dashboard Nigeria. 2021. Available online: https://www.unfpa.org/data/ world-population/NG (accessed on 30 November 2021).

62. Jimenez, E.; Pate, M. Reaping a dividend in Africa's largest country: Nigeria. In Africa's Population: In Search of a Demographic Dividend; Groth, H., May, J.F., Eds.; Springer: Dordrecht, The Netherlands, 2017; pp. 33-51. 
63. Etebong, P. Demography in Nigeria: Problems and prospects. Biostat. Biom. Open Access J. 2018, 5, 1-6.

64. Oduwole, T. Youth unemployment and poverty in Nigeria. Int. J. Sociol. Anthropol. Res. 2015, 1, $23-39$.

65. Boumphery, S. World's fastest growing cities in Asia and Africa. Euromonitor International. 2010. Available online: https://www. euromonitor.com/article/special-report-worlds-fastest-growing-cities-are-in-asia-and-africa (accessed on 3 November 2021).

66. National Bureau for Statistics. Population 2006-2016. 2016. Available online: https://nigerianstat.gov.ng/elibrary?queries[search] =population (accessed on 29 October 2021).

67. Abubakar, I.R. Abuja city profile. Cities 2014, 41, 81-91. [CrossRef]

68. Okwu-Delunzu, V.U.; Oweifighe, W.J.; Ugochukwu, U.C. Assessment of Air Quality Levels in Heavy Traffic Areas in Enugu urban, Nigeria. In Monograph of Atmospheric Research 2018; Centre for Atmospheric Research: Anyigba, Nigeria, 2018. Available online: https:/ / carnasrda.com/wp-content/uploads/2019/06/Okwu-et-al.pdf (accessed on 30 October 2021).

69. Agu, C.C.; Ikwuka, A.; Tukur, K.; Omede, H.; Nwadike, B.K. An Assessment of Heatwave Impact in Enugu Metropolis of Enugu State. 2020. Available online: https:/ / assets.researchsquare.com/files/rs-36863/v3/4ab6cf24-a963-451d-bb77-ec15f11fcff9.pdf? c=1631861464 (accessed on 20 November 2021).

70. Metrotrends. Enugu, Nigeria Metro Area Population 1950-2020. 2020. Available online: https://www.macrotrends.net/cities/21 986/enugu/population (accessed on 25 October 2021).

71. Odoemena, A.; Olaoba, O. Explaining inter-ethnic harmony in Enugu city, South-eastern Nigeria, 1970-2003. Afr. J. Confl. Resolut. 2010, 10, 111-136. [CrossRef]

72. Sunday, O.M. Critical factors determining public transport access level in Abuja federal capital territory of Nigeria. J. Geogr. Reg. Plan. 2017, 10, 298-308. [CrossRef]

73. Ashara, A.; Saleh, S.; Hassan, U.; Kaura, M. Traffic Management System in Abuja City Center, using Geographic Information Systems (GIS) and Global Positioning System (GPS). A case study of FCT, Nigeria. J. Phys. Conf. Ser. 2020, 1529, 052068. [CrossRef]

74. National Bureau of Statistics. Road Transport Data. 2018. Available online: https://www.nigerianstat.gov.ng/pdfuploads/Road_ Transport_Data_-_Q2_2018.pdf (accessed on 28 October 2021).

75. National Bureau of Statistics. Power Sector Report: Energy Generated and Sent Out and Consumed and Load Allocation. 2019. Available online: https://www.nigerianstat.gov.ng/pdfuploads/Power_Generation_-_Q4_2018.pdf (accessed on 5 November 2021).

76. Kadafa, A.A. Solid Waste Management Practice of Residents in Abuja Municipalities (Nigeria). IOSR J. Environ. Sci. 2017, 11, 87-106. [CrossRef]

77. Amalu, T.E.; Ajake, A.O. Appraisal of Solid Waste Management Practices in Enugu City, Nigeria. 2014, Volume 4. Available online: www.iiste.org (accessed on 20 October 2021).

78. Hamid, A.A.; Usman, L.A.; Elaigwu, S.E.; Zubair, M.F. Environmental and Health Risk of Bush Burning. Adv. Environ. Biol. 2010, $4,241-249$.

79. Abaje, I.B.; Bello, Y.; Ahmad, S.A. A Review of Air Quality and Concentrations of Air Pollutants in Nigeria. J. Appl. Sci. Environ. Manag. 2020, 24, 373-379. [CrossRef]

80. Fagbeja, M.; Olumide, O.; Rabiu, B. An Overview of AQ Monitoring and Prediction in Nigeria. 2017. Available online: https: / / docplayer.net/88477418-An-overview-of-aq-monitoring-and-prediction-in-nigeria.html (accessed on 7 November 2021).

81. Federal Ministry of Youths and Sports. National Youth Policy. Enhancing Youth Development and Participation in the Context of Sustainable Development. 2019. Available online: https://www.prb.org/wp-content/uploads/2020/06/Nigeria-NationalYouth-Policy-2019-2023.pdf (accessed on 7 November 2021).

82. Wiedmaier, B. Post Hoc Tests. In The SAGE Encyclopedia of Communication Research Methods; SAGE Publications: Thousand Oaks, CA, USA, 2017. [CrossRef]

83. Xia, Y. Correlation, and association analyses in microbiome study integrating multiomics in health and disease. Prog. Mol. Biol. Transl. Sci. 2020, 171, 309-491. [CrossRef]

84. Oltra, C.; Sala, R. A Review of the Social Research on Public Perception and Engagement Practices in Urban Air Pollution; CIEMAT/Departamento de Medio Ambiente: Madrid, Spain, 2014.

85. Bickerstaff, K.; Walker, G. Public understandings of air pollution: The 'localisation' of environmental risk. Glob. Environ. Chang. 2001, 11, 133-145. [CrossRef]

86. Conti, C.; Guarino, M.; Bacenetti, J. Measurements techniques and models to assess odour annoyance: A review. Environ. Int. 2020, 134, 105261. [CrossRef] [PubMed]

87. Bickerstaff, K. Risk perception research: Socio-cultural perspectives on the public experience of air pollution. Environ. Int. 2004, 30, 827-840. [CrossRef] [PubMed]

88. Smallbone, K. Individuals' Interpretation of Air Quality Information. 2019. Available online: https://research.brighton.ac.uk/ files/336785/1210261047_Individuals_interpretation_of_air_quality_information_customer_insight_and_awareness_study.pdf (accessed on 6 October 2021).

89. Cometto-Muñiz, J.; Cain, W. Part iii. Assessing irritation: Sensory irritation: Relation to indoor air pollution. Ann. N. Y. Acad. Sci. 1992, 641, 137-151. [CrossRef] [PubMed]

90. Golden, R.; Holm, S. Indoor Air Quality and Asthma: Has Unrecognized Exposure to Acrolein Confounded Results of Previous Studies? Dose Response 2017, 48, 314-315. [CrossRef] 
91. Nielsen, G.D.; Wolkoff, P. Evaluation of airborne sensory irritants for setting exposure limits or guidelines: A systematic approach. Regul. Toxicol. Pharmacol. 2017, 90, 308-317. [CrossRef]

92. Ancelet, T.; Davy, P.K.; Trompetter, W.J.; Markwitz, A. Sources of particulate matter pollution in a small New Zealand city. Atmos. Pollut. Res. 2014, 5, 572-580. [CrossRef]

93. Jacobi, P.R. Households and Environment in the City of Sao-Paulo-Problems, Perceptions and Solutions. Environ. Urban. 1994, 6, 87-110. [CrossRef]

94. Emodi, E.E. Environmental degradations, strategies and effective management practices in Enugu, Nigeria. Merit Res. J. 2017, 5, $35-45$.

95. Eze, C.T.; Ugwoke, J.L.; Ugwoke, J.J. Road traffic congestion and vehicular emission in Enugu urban Nigeria. Environ. Biotechnol. J. 2019, 38, 1-8.

96. Ndoke, P.N.; Akpan, U.G.; Kato, M. Contributions of Vehicular Traffic to Carbon Dioxide Emissions in Kaduna and Abuja, Northern Nigeria. 2006. Available online: https://www.semanticscholar.org/paper/Contributions-of-Vehicular-Traffic-toCarbon-in-and-Ndoke-Akpan/7b30e54f4ba1a5d2851460a0e460af583f91bd40 (accessed on 12 October 2021).

97. Hassan, S.; Okobia, L. Survey of ambient air quality in some parts of the Federal Capital Territory, Abuja, Nigeria. J. Geogr. Dev. 2008, 2, 3-17.

98. Wambebe, N.; Xiaoli, D. Ambient Air Quality Assessment within Abuja Municipal Area, Nigeria. Environ. Epidemiol. $2019,3,421$. [CrossRef]

99. World Health Organization. Promoting Walking and Cycling. Available online: https://www.who.int/activities/promotingwalking-and-cycling (accessed on 4 December 2021).

100. Ukiwo, U. Violence, Identity Mobilization and the Reimagining of Biafra. Afr. Dev. 2009, 34, 9-30. [CrossRef]

101. Onuoha, G. The presence of the past: Youth, memory making and the politics of self-determination in Southeastern Nigeria. Ethn. Racial Stud. 2013, 36, 2182-2199. [CrossRef]

102. Njoku, R. African Cultural Values; Taylor and Francis: London, UK, 2013.

103. Agbaji, D.; Akhabue, G.; Duruaku, D.; Egor, F.; Ogban, K.; Pepple, U. Combating Youth Restiveness in Nigeria: Proferring Workable Solutions. Am. J. Humanit. Soc. Sci. Res. 2018, 2, 65-73.

104. Bello, D.T.T. The Role of the Youth in the Electoral Process in Nigeria Politics: From Historical Appraisal. IOSR J. Humanit. Soc. Sci. IOSR-JHSS 2019, 24, 18-29. [CrossRef]

105. Venter, Z.S.; Aunan, K.; Chowdhury, S.; Lelieveld, J. COVID-19 lockdowns cause global air pollution declines. Proc. Natl. Acad. Sci. USA 2020, 117, 18984-18990. [CrossRef]

106. Agarwal, A.; Kaushik, A.; Kumar, S.; Mishra, R.K. Comparative study on air quality status in Indian and Chinese cities before and during the COVID-19 lockdown period. Air Qual. Atmos. Health 2020, 13, 1167-1178. [CrossRef]

107. Sharma, S.; Zhang, M.; Anshika; Gao, J.; Zhang, H.; Kota, S.H. Effect of restricted emissions during COVID-19 on air quality in India. Sci. Total. Environ. 2020, 728, 138878. [CrossRef]

108. Anil, I.; Alagha, O. The impact of COVID-19 lockdown on the air quality of Eastern Province, Saudi Arabia. Air Qual. Atmos. Health 2021, 14, 117-128. [CrossRef] [PubMed]

109. Olusola, J.A.; Shote, A.A.; Isaifan, R.J.; Ouigmane, A. The impact of COVID-19 pandemic on nitrogen dioxide levels in Nigeria. Peer] 2021, 9, e11387. [CrossRef] [PubMed]

110. Mogaji, E. Impact of COVID-19 on transportation in Lagos, Nigeria. Transp. Res. Interdiscip. Perspect. 2020, 6, 100154. [CrossRef] [PubMed] 